EDSON OLIVEIRA PEREIRA

ACESSO E QUALIDADE DA ATENÇÃO À SAÚDE PARA A POPULAÇÃO

LGBT: A VISÃO DOS MÉDICOS DE UMA CAPITAL DO NORDESTE BRASILEIRO.

Brasília, 2015 
UNIVERSIDADE DE BRASÍLIA

FACULDADE DE CIÊNCIAS DA SAÚDE

PROGRAMA DE PÓS-GRADUAÇÃO EM SAÚDE COLETIVA

EDSON OLIVEIRA PEREIRA

ACESSO E QUALIDADE DA ATENÇÃo À SAÚDE PARA A POPULAÇÃO

LGBT: A VISÃO DOS MÉDICOS DE UMA CAPITAL DO NORDESTE

BRASILEIRO.

Dissertação apresentada ao Programa de Pós Graduação em Saúde Coletiva, como requisito para a obtenção do título de Mestre em Saúde Coletiva - Mestrado Profissional, na linha de pesquisa de Políticas, Planejamento, Gestão e Atenção em Saúde.

Orientador: Claudio Garcia Fortes Lorenzo.

Brasília, 2015 


\title{
ACESSO E QUALIDADE DA ATENÇÃO À SAÚDE PARA A POPULAÇÃO LGBT: A VISÃO DOS MÉDICOS DE UMA CAPITAL DO NORDESTE BRASILEIRO.
}

\begin{abstract}
Dissertação apresentada ao Programa de Pós Graduação em Saúde Coletiva, como requisito para a obtenção do título de Mestre em Saúde Coletiva - Mestrado Profissional, na linha de pesquisa de Políticas, Planejamento, Gestão e Atenção em Saúde.
\end{abstract}

\section{BANCA EXAMINADORA:}

\author{
Prof. Dr. Claudio Garcia Forte Lorenzo \\ Presidente
}

Profa. Dra. Maria Fátima de Souza

Examinadora Titular do Programa

Dr. Edu Turte Cavadinha

Examinador Externo

Profa. Dra. Ana Valéria Machado Mendonça

Examinadora Suplente 
Eu posso ser quem eu quiser ser, еи posso ser о que pensam que еи sеja, o que querem que еи sеja, ser o que Deus sonhou pra eu ser. Eu quero ser o que escolhi ser, quero ainda, que todos vivam em paz com suas escolhas de ser... 


\section{AGRADECIMENTOS}

Ao meu Deus, pelo cuidado, proteção e carinho recebidos durante toda a minha vida, sem o Seu amor infinito não conseguiria guerrear, quando em tempos difíceis, Sua mão me sustentava e me guiava a tempos melhores.

Aos meus pais, Celino de Almeida Pereira e Maria Lima de Oliveira Pereira, pelos primeiros e essenciais ensinamentos de amor, fazendo de mim extensão dos seus caráteres e de suas personalidades, aos senhores, meus pais, devo a vida.

A meu irmão Edmar, minha cunhada Adriana e meu sobrinho Breno por todo carinho, atenção e compreensão. Vocês são joias preciosas em minha vida, peças fundamentais para minha felicidade.

Aos queridos Álvaro Montenegro, Márcia Montenegro, Jeová Carvalho e Valdeci Carvalho, pais de coração, em muitas vezes se preocupavam, aconselhavam e repreendiam, todos os atos de amor e carinho para comigo, nunca serão esquecidos. Estendo os agradecimentos ainda, aos queridos irmãos de coração, Décio Montenegro, Karen Montenegro (in memoriam) e Abner Carvalho, com vocês aprendi que há amigos mais chegados que um irmão.

Ao orientador Claudio Lorenzo, pessoa especial, pela paciência, tolerância, calma e sabedoria ao lidar com meus sonhos e projetos. Obrigado não apenas por tudo isso, mas por me tornar uma pessoa melhor, me mostrando através de sua amizade que é possível acreditar naquilo que se sonha.

Aos Professores e todo corpo técnico da Faculdade de Ciências da Saúde da Universidade de Brasília, em especial a Valéria Mendonça, pelo prazer da convivência e da troca de experiências.

Ao Grupo de Pesquisa “Saúde LGBT" do Nesp UFPI e UnB, Dr. José Ivo, Dra. Flávia Teixeira, Dra. Elaine Costa, Dr. Edu Cavadinha e em especial a coordenadora da pesquisa, Fátima Sousa pela humildade e paciência ao repassar tão valiosos conhecimentos e experiências.

Aos colegas de turma, pela companhia e por todo apoio recebido, sei que nossa relação de troca de experiências muito nos ensinou, dentre eles, como não citar Antônio Alves, Bianca Moura, Ione Silva e Talita Mosqueta pela cumplicidade, vocês me ensinaram a forma mais fácil possível de conhecer e passar pela universidade. Antônio Alves, em especial, pelo cuidado e ensinamentos, demonstrando os valores de uma verdadeira amizade. 
A Gabriela Sorgatto e Siliana Martins pela cumplicidade e motivação, fazendo de mim uma pessoa melhor.

Ao HU da Universidade Federal do Piauí, pela compreensão no início dessa empreitada, em especial a quem nunca mediu esforços para o meu crescimento e a quem serei grato eternamente, Socorro Costa.

A Zaira Mesquita, Flávia Negreiros, Luiz Fernando, Irene Cavalcante, Milton Lima, Daniel Lacerda e em especial, Breno Ferreira, por tornar mais fácil e agradável essa fase decisiva em minha vida, devo a vocês os verdadeiros votos de gratidão.

Por fim, agradeço a todos que estiveram e continuam, aos que já andaram comigo e aos que ainda andam, sei que nem todos os tesouros desta terra se comparam a diversidade e riqueza de amigos que possuo. Muito obrigado! 


\section{RESUMO}

A presente dissertação teve como objetivo discorrer no campo teórico sobre a formação de estigma para a diversidade sexual, heteronormatividade e homofobia, bem como sobre a ação desses fatores sobre a saúde da população LGBT, as reações de enfrentamento dos movimentos sociais e suas influências sobre elaboração de políticas públicas. A dissertação apresenta como resultado prático um artigo fruto de um estudo que investigou a percepção de médicos de unidades básicas sobre o acesso e a qualidade de atenção à população LGBT. A amostra foi formada pelos discursos transcritos após entrevista semiestruturada com profissionais médicos de sete Unidades de Saúde da Família de diferentes regiões de Teresina, capital piauiense, entre as 22 existentes, e examinadas pelo método hermenêutico-dialético por meio do qual se pretendeu demonstrar as ideologias e moralidades subjacentes às falas. Quatro principais categorias analíticas emergiram: 1. Percepção confusa entre universalidade e equidade, 2. Patologização e percepção de anormalidade na condição, 3. Negação de barreira ao acesso e imputabilidade da ausência de procura do serviço aos próprios sujeitos, e 4. Baixa demanda do grupo LGBT ou invisibilidade da condição. Os resultados da presente pesquisa apontam para a substantiva relação estigmatizante entre os profissionais médicos entrevistados com a população LGBT. Evidenciando o grande desafio que é a implementação da Política Nacional de Saúde Integral da População LGBT e a forte necessidade da mudança na perspectiva médica quanto ao respeito à diversidade sexual. É notória a necessidade da aplicação e fortalecimento de ações eficientes que visem a mudança dos pensamentos e práxis da classe médica com vistas a diminuir os processos de violência simbólica, estigmas e LGBTfobia.

PALAVRAS CHAVE - Identidade Sexual; Políticas Públicas De Saúde; Equidade Em Saúde; Homossexualidade. 


\begin{abstract}
This work aims to discuss the theoretical field on stigma training for sexual diversity, heteronormativity and homophobia, as well as the effect of these factors on the health of the LGBT population, coping reactions of social movements and their influences on development public policy. The dissertation presents practical result as a fruit article from a study investigating the perception of medical basic units on access and quality of care to the LGBT population. The sample was formed by transcribed speeches after semistructured interviews with medical professionals from seven health units of the Family from different regions of Teresina, Piauí capital, among the 22 existing and examined by the hermeneutic-dialectic method by which it was intended to demonstrate the ideologies and underlying morals to task. Four key analytical categories emerged: 1. confused perception between universality and equity, and 2. Pathologization perception abnormality condition, barrier 3. Denial of access and accountability to the lack of demand for the service to the subjects themselves, and 4. Low demand LGBT group or invisibility of the condition. The results of this study point to the substantive relationship stigmatizing among medical professionals interviewed with the LGBT population. Highlighting the major challenge is the implementation of the National Policy on Comprehensive Health of LGBT population and the strong need for change in medical perspective on the respect for sexual diversity. These findings emphasize the need for the implementation and strengthening of efficient actions aimed at changing the thinking and practice of the medical profession to diminish the processes of symbolic violence, stigma and LGBTfobia.
\end{abstract}

KEY WORD- Sexual identity; Public Policy Health Care ; Equity in Health ; Homosexuality. 


\section{LISTA DE ABREVIATURAS}

AB- Atenção Básica.

AIDS- Síndrome da Imunodeficiência Adquirida.

APS- Atenção Primária à Saúde.

CEBES- Centro Brasileiro de Estudos em Saúde.

CNES- Cadastro Nacional dos Estabelecimentos de Saúde.

DST- Doença Sexualmente Transmissível.

ESF- Estratégia Saúde da Família.

GGB- Grupo Gay da Bahia.

HIV- Vírus da Imunodeficiência Humana.

LGBT- Lésbicas, Gays, Bissexuais, Travestis e Transexuais.

MS- Ministério da Saúde.

OMS- Organização Mundial de Saúde.

PI- Piauí.

PNAIPLGBT- Política Nacional de Atenção Integral da População LGBT.

PNDH- Plano Nacional de Desenvolvimento Humano.

SF- Saúde da Família.

SUS- Sistema Único de Saúde.

TB- Tuberculose.

UBS- Unidade Básica de Saúde.

USF- Unidade de Saúde da Família. 
APRESENTAÇÃO........................................................................................ 11

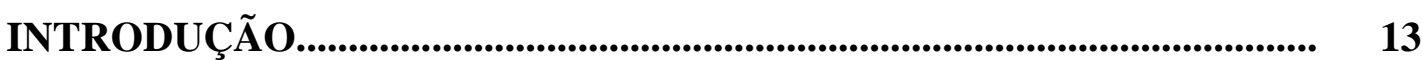

REFERENCIAL TEÓRICO E REVISÃO DE LITERATURA...................... 15

Heteronormatividade, Estigma e Homofobia................................................. 15

Diversidade Sexual e Ações de Saúde............................................................. 30

METODOLOGIA DA DISSERTAÇÃO........................................................... 36

RESULTADOS E DISCUSSÕES.................................................................... 38

Artigo: Unidades Básicas de Saúde em Teresina-PI e o acesso da população LGBT: o que pensam os médicos?....................................... 39

CONSIDERAÇÕES FINAIS DA DISSERTAÇÃO............................................. 61

REFERÊNCIAS...............................................................................................62

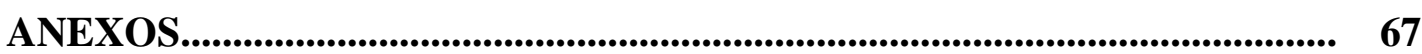

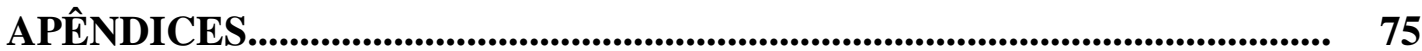




\section{APRESENTAÇÃO}

Atualmente, com a consolidação da Saúde da Família e crescimento dos serviços da Atenção Básica, há uma necessidade de aprofundar as análises na perspectiva de analisar suas ações e os serviços. Com isso, é fundamental a realização de estudos que possam reconhecer caminhos que vêm sendo traçados com vistas a enfrentar os desafios para qualificação de toda Atenção Básica.

Dentro desse contexto, ressalta-se a necessidade imperiosa em investigar o acesso das pessoas aos estabelecimentos e serviços de saúde a população de Lésbicas, Gays, Bissexuais, Travestis e Transexuais (LGBT) e, ainda, dentro dessa lógica, evidenciar os possíveis agentes facilitadores, como também os óbices, este último de forma mais profunda.

O referencial teórico desenvolvido busca abordar os conceitos, a evolução e os principais fins que a sexualidade possui ao longo do tempo e que, na maioria das vezes, explica fenômenos e ações atuais, inclusive os contextos de violência, abordados de forma peculiar nesta fase do trabalho. Os caminhos metodológicos traçados nesta pesquisa buscam ir ao encontro dos pressupostos legais e éticos estabelecidos, explícitos nos instrumentos e, consequentemente, ao longo das ações práticas da pesquisa.

Assim, os resultados e discussões são apresentados no artigo intitulado “Unidades Básicas de Saúde em Teresina-PI e o acesso da população LGBT: o que pensam os médicos?", submetido à Revista Tempus Actas de Saúde Coletiva, da Universidade de Brasília, busca por meio dos seus resultados analisados e da discussão da proposta metodológica, evidenciar a forma de pensar da classe médica de sete Unidades de Saúde da Família situadas na capital do Piauí em relação ao acesso da população LGBT no Sistema Único de Saúde, tomando como porta de entrada a Estratégia Saúde da Família.

As considerações finais apontam a necessidade de continuar apostando em ações que fortaleçam o acesso da população LGBT, que foi historicamente negligenciado e marcado por violências físicas, morais e simbólicas. Este trabalho reconhece as iniciativas do Governo Federal como potentes ferramentas de transformação, porém o fortalecimento através do diálogo em elementos sociais capilarizados, envolvendo a comunidade e, principalmente, os profissionais médicos, evidenciados nesse estudo 
como agentes cujas ações desencontram ao positivado na Política Nacional de Atenção Integral a População LGBT. 


\section{INTRODUÇÃO}

O Art. 196 da Constituição Federal de 1988 define que "saúde é direito de todos e dever do Estado, garantido mediante políticas sociais e econômicas que visem à redução do risco de doença e de outros agravos e ao acesso universal e igualitário às ações e serviços para sua promoção, proteção e recuperação" (BRASIL, 1988).

A discriminação por orientação sexual e por identidade de gênero incide na determinação social da saúde ao desencadear processos de sofrimento, adoecimento e morte prematura decorrentes do preconceito e do estigma social reservado às lésbicas, gays, bissexuais, travestis e transexuais.

A Política Nacional de Saúde para Lésbicas, Gays, Bissexuais, Transexuais e Travestis - LGBT, reafirma o compromisso do SUS (Sistema Único de Saúde) com a universalidade, a integralidade e com a efetiva participação da comunidade e, por isso, contempla ações voltadas para a promoção, prevenção, recuperação e reabilitação da saúde, além do incentivo à produção de conhecimentos e o fortalecimento da representação do segmento nas instâncias de participação popular.

O primeiro desafio da população LGBT no sistema de saúde é o acesso a ele, seguido pela incerteza de um acolhimento humanizado e um atendimento livre de qualquer discriminação pela orientação sexual ou identidade de gênero que pode ser ainda atrelada a outros fatores como idade, cor, classe social dentre outros. Outro grande fator determinante numa atenção integral e promotora de equidade consiste ainda nos encaminhamentos específicos desse público quando a unidade de saúde não fornece os serviços necessários para resolutividade dos problemas.

Sendo que a principal ferramenta de acesso ao sistema de saúde, na Atenção Básica, consiste na Estratégia de Saúde da Família (ESF), é necessária uma ampla conscientização, por parte da gestão, das diferentes modalidades de constituição de redes familiares distintas do padrão heterossexual, além do direito ao livre desenvolvimento, o que inclui a orientação sexual e a identidade de gênero.

Os direitos à privacidade, à autonomia e ao livre desenvolvimento da personalidade devem ser preservados, através de amplo reconhecimento da diversidade das possibilidades eróticas e subjetivas, primando pelo respeito à singularidade dos sujeitos e combatendo todas as formas de normatização que impliquem em processos de exclusão e de discriminação das pessoas (LIONÇO, 2008). 
A universalidade do direito à saúde requer que se proponham estratégias de promoção da equidade, através de acolhimento e atenção específicos, de acordo com as particularidades dos sujeitos que buscam os serviços de saúde. Isso Implica a compreensão de que a orientação sexual e a identidade de gênero são determinantes que estão articulados a outros condicionantes, tais como classe social, idade, cor e etnia.

Para Mello et al. (2011), no âmbito das reflexões sobre acesso da população LGBT a serviços de saúde fundados nos princípios de universalidade, integralidade e equidade, note-se que orientação sexual e identidade de gênero não devem ser cogitadas como atributos identitários ou marcadores sociais únicos, já que necessariamente se articulam de formas diversas com outros, a exemplo de idade, raça/cor e classe social.

A focalização de ações e políticas específicas é um recurso necessário, muitas vezes, para a própria efetivação da universalidade, mediante promoção da equidade entre grupos em situação desigual. A proposição de políticas específicas, no entanto, sobretudo referentes à problemática que não dispõe de um acúmulo reflexivo no próprio âmbito da gestão encontra como fator dificultador, e mesmo impeditivo, como é o caso da população LGBT (LIONÇO, 2008).

Faz-se necessário, fundamentalmente, reafirmar a universalidade dos direitos humanos, dentre os quais o direito à saúde, resgatando LGBT como sujeitos de direitos, já que os processos de estigma e discriminação vêm comprometendo o seu exercício da cidadania. Caso resguardados os princípios ético-políticos do SUS em sua efetiva consolidação, o sistema de saúde brasileiro pode ser uma ferramenta política e social privilegiada para o combate à homofobia e demais estratégias correlatas de violação dos direitos humanos fundamentais (BRASIL, 2010).

O município de Teresina, capital piauiense, apresenta a Estratégia Saúde da Família (ESF) em praticamente todos os bairros da cidade, cobrindo uma população de 759.000 pessoas, o que representava $95,6 \%$ da população geral, possuindo 72 Centros de Saúde/Unidades Básicas de Saúde e 220 equipes de saúde da família, distribuídas nas áreas urbana e rural. Por outro lado, a capital ocupa posições preocupantes no que se refere aos altos índices de violências à população LGBT, de acordo relatórios anuais do Grupo Gay da Bahia.

O objetivo desse estudo é discorrer sobre a formação de estigma, heteronormatividade e homofobia, discutindo seus impactos na saúde e as reações dos 
movimentos sociais e políticas públicas, como também apresentar um artigo que analisa a percepção de médicos de unidades básicas da cidade de Teresina sobre o acesso e qualidade de atenção à população LGBT.

\title{
REFERENCIAL TEÓRICO E REVISÃO DE LITERATURA
}

\section{Heteronormatividade, Estigma e Homofobia.}

Para uma evidenciação mais correta acerca da evolução do conceito de heteronormatividade, faz-se necessária a abordagem prévia do conceito de sexualidade, refletindo o valor simbólico e cultural carregada pela temática, para que assim, possa-se entender o processo de construção da sociedade e sabendo que esse processo influenciou diretamente no estabelecimento das relações sociais, afetivas e sexuais da população LGBT.

Em um enfoque mais recente Weeks define sexualidade como:

\begin{abstract}
Uma construção histórica, que reúne uma série de diferentes possibilidades biológicas e mentais, e formas culturais - identidade de gênero, diferenças corporais, capacidade de reprodução, necessidades, desejos, fantasias, práticas eróticas, instituições e valores - as quais não necessariamente estão relacionadas dessa forma, e em outras culturas de fato não estão. Todos os elementos constituintes da sexualidade têm como base o corpo e a mente, e aqui não estou tentando negar os limites colocados pelos processos biológicos e mentais. Mas as capacidades do corpo e da psique adquirem sentido/significado somente em meio a relações sociais. [...] precisamos aprender a ver que a sexualidade é algo que é produzido pela sociedade por meio de caminhos complexos. Que ela é resultado de uma diversidade de práticas sociais e auto definições, de lutas entre aqueles que têm o poder de definir e regular e daqueles que resistem. A sexualidade não é dada, ela é produto de negociação, luta e agência humana. (WEEKS, 2003, p. 7;19)
\end{abstract}

Porém, nem sempre a sexualidade esteve nessa vertente conceitual voltada a essas diferentes possibilidades biológicas e mentais e muito menos numa visão de algo que é produzido socialmente por caminhos admitidos por Weeks, como complexos. Durante muitos anos na história da humanidade, a sexualidade era restrita a um conceito reprodutivo, sendo os órgãos genitais seus únicos objetos de execução. Com o passar do tempo, mais precisamente nas últimas décadas, a sexualidade deixa de estar somente vinculada ao conceito de reprodução, de pecado ou impureza e passa a compreender outras vertentes, invadindo em seu conceito os campos sentimentais, além das mais diversas formas de relações humanas.

A Scientia Sexualis caracterizou o surgimento na Idade Moderna da sexualidade, sendo adotado pela região ocidental, a fim de produzir um discurso verdadeiro sobre o sexo. Essa verdade que até então só era obtida através da confissão, estava sob o 
domínio da Igreja Católica desde o século XVI, mantendo domínio sobre as experiências sexuais, esse controle se manteve até o século XIX. Assim, a Scientia Sexualis, é entendida como "forma de poder-saber para dizer a verdade do sexo" (TESHAINER, 2008, p.229).

O discurso científico passou a se atrelar a imperativos morais que sustentavam as normas médicas. Estas, por sua vez, no intuito de dizer a verdade, prescreviam cuidados, condenavam hábitos e localizavam discrepâncias, alertando para perigos em toda parte, com o objetivo de "assegurar o vigor físico e a pureza moral do corpo social" (FOUCAULT, 2001, p. 54).

Foucault aborda a herança deixada pelo regime de castidade imperial, imprimida em nossa sexualidade "contida, muda e hipócrita". "Parece que por muito tempo, teríamos suportado um regime vitoriano e a ele nos sujeitamos ainda hoje" (FOUCAULT, 1976, p.9), se referindo a sexualidade como uma forma oculta às pessoas não adultas, dotada de proibições e carregada de interdições apoiadas em interesses discursivos. O que não era realidade no início desse mesmo século, pois ainda vigorava um modelo mais liberal e aberto, quando comparado ao século XIX.

Esse momento histórico é registrado por Foucault (1976) no livro História da Sexualidade I: A vontade de saber e elucida esse acontecimento brusco entre os séculos XVII e o século XIX, citado por ele como o "encerramento da sexualidade", dando assim origem ao que futuramente foi nomeado como heteronormatividade por Michael Warner, no século XX, restringindo os sujeitos, o espaço, o modo e a função da sexualidade:

\begin{abstract}
A sexualidade é, então, cuidadosamente encerrada. Muda-se para dentro de casa. A família conjugal a confisca. E absorve-a, inteiramente, na seriedade da função de reproduzir. Em torno do sexo, se cala. O casal, legítimo e procriador, dita a lei. Impõe-se como modelo, faz reinar a norma, detém a verdade, guarda o direito de falar, reservando-se o principio do segredo (FOUCAULT, 1976, p. 9, 10).
\end{abstract}

Assim, esses processos contínuos de controle foram determinados pelos vários dispositivos da sexualidade implantados desde o século XVII até os nossos dias. O século XIX, especialmente, foi auge destes processos de controle, uma vez que se caracterizou por influências diretas de ideias científicas e biologizantes da corrente filosófica positivista, determinadas por modelos de controle e poder que coibiam a sexualização da criança, a esterilização sexual da mulher e a regulação das populações, 
determinando os meios e a finalidade da sexualidade, transformando-a em processos de controle da sociedade.

As determinações espirituais teve um grande peso e ainda influencia os arranjos sociais no âmbito da sexualidade. O que hoje está embutido em discursos públicos e posicionamentos hipócritas era claramente determinado e imposto, "Ao clero, homens do mundo espiritual, deveria caber a castidade e o poder. Aos leigos, homens do mundo profano, caberia o matrimônio e a obediência” (VAINFAS, 1986, p. 34-35).

E por muito tempo a sexualidade foi uma arma nas mãos de instituições dominadoras. A história do cristianismo faz constante referência à questão da sexualidade, já que com o objetivo de consolidar e expandir seu poder político, a igreja procurou assegurar o controle sobre a sexualidade das pessoas (DANTAS, 2010).

Assim, esse conceito de sexualidade como meramente restringido a relação sexual e reprodução foi mantido por muito tempo, e seu fim é marcado pela revolução industrial, devido às alterações sociais provocadas nesse período. Segundo Pereira, a sexualidade passou a ser notada em emoções, sentimentos e ainda nas relações humanas e fraternais:

\footnotetext{
"a sexualidade deixou, pois, de ser sinônimo de reprodução, de pecado e de impureza para passar a fazer parte integrante dos afetos, do prazer, da comunicação interpessoal, da maternidade e da paternidade responsáveis" (PEREIRA, 2001, p. 13).
}

A sexualidade passa, portanto, a ser parte integrante da vida de todo o ser humano, que se inicia na relação materno-fetal, perpetuando até o final da vida. Durante essa trajetória de vida, a sexualidade passa a ser moldada por diversos fatores que interferem na personalidade do sujeito, determinando assim sua identidade sexual. Sigmund Freud já afirmava que o desenvolvimento da sexualidade está presente desde a infância, acrescentando que as crianças se auto manipulavam em busca de prazer. Inicialmente tratar-se-ia de um prazer oral, depois anal e por fim tomaria a forma de prazer genital (Freud, s.d./1924).

São diversos os estudos acerca da sexualidade, dividido em diversas áreas do saber, o que culminou numa vasta dimensão do conhecimento da temática sexualidade. Embora os avanços sejam consideráveis, existem ainda diversas dúvidas acerca da significação da sexualidade, já que atualmente ainda vigoram perspectivas tradicionais. Foucault, de já, elucidou acerca dessa flexibilidade da sexualidade: 
Nas relações de poder, a sexualidade não é o elemento mais rígido, mas um dos dotados de maior instrumentalidade: utilizável no maior número de manobras, e podendo servir de ponto de apoio, de articulação às mais variadas estratégias (FOUCAULT, 2007, p. 98).

Cortesão (1989 p. 15) cita cinco tipos de perspectivas tradicionais: Perspectiva Reprodutiva, Perspectiva genital, Perspectiva Masculina, Perspectiva Adulta e Perspectiva Heterossexual.

A perspectiva reprodutiva limita a sexualidade para fins reprodutivos, já na perspectiva genital o foco é basicamente nos órgãos genitais e no coito vaginal. A perspectiva masculina aborda as questões de gênero e o desempenho de seus papeis, sendo que na perspectiva do adulto surge associada ao matrimônio e, finalmente, a perspectiva heterossexual diz respeito à relação amorosa exclusivamente estabelecida entre homem e mulher, na qual origina a normatização do padrão heterossexual (CORTESÃO, 1989).

Dentro dessas perspectivas tradicionais, observam-se os princípios da heteronormatividade arraigados em suas definições, seja no padrão sexual ou ainda na definição comportamental e divisão dos papeis sociais, fazendo assim entender que a heteronormatividade sempre esteve permeando o meio social desde muito tempo, o que não sugere é que a homossexualidade foi "inventada" ou surgiu depois da heterossexualidade, para que assim pudesse tentar justificar essa superioridade histórica.

Embora a homossexualidade seja referida como existente em todas as sociedades humanas e em todas as épocas, com variadas e diversificadas denominações, até os dias atuais ela ainda não é considerada e nem tampouco reconhecida como uma condição normal por diversos segmentos sociais, devido à padronização da heteronormatividade, que reconhece e define o homem e mulher como únicas categorias sexuais, não aceitando qualquer outro arranjo que ultrapasse esses padrões:

\footnotetext{
Por heteronormatividade, entende-se a reprodução de práticas e códigos heterossexuais, sustentada pelo casamento monogâmico, amor romântico, fidelidade conjugal, constituição de família (esquema pai-mãe-filho(a)(s)). $\mathrm{Na}$ esteira das implicações da aludida palavra, tem-se o heterossexismo compulsório, sendo que, por esse último termo, entende-se o imperativo inquestionado e inquestionável por parte de todos os membros da sociedade com o intuito de reforçar ou dar legitimidade às práticas heterossexuais (FOSTER, 2001, p. 19).
}

Miranda (2010) na busca de compreender o estabelecimento na sociedade do termo heteronormatividade, pode observar que a tendência à sexualidade normalizante sempre existiu, quando nos discursos impressos descrevem a condição homossexual 
como desvio. E a mudança dessa condição social não impediu que a heteronormatividade imperasse nas relações sociais até os dias atuais.

A ação da heteronormatividade na divisão dos sexos em apenas duas categorias não influencia apenas na identidade sexual, mas invade diversos campos sociais, como a regulação que divide o mercado de trabalho, normatizando as profissões de forma que arranjos sexuais diferentes daqueles que envolvam o homem e a mulher estejam extintos. Dentre esses campos, também padroniza o casamento heterossexual como parte da matriz da sociedade.

Percebe-se assim, que como consequência dessa padronização heteronormatizada da sexualidade, aqueles que não foram regulados para a geração ou por ela alterados e modificados não possui valor social ou até mesmo legal. Para Foucault (1976), essa repressão condena ao desaparecimento, ou ainda, na imposição ao silêncio e na afirmação de inexistência, o que no campo na saúde influencia diretamente no estado de saúde desses indivíduos desde os aspectos fisiológicos e psicológicos.

A heteronormatividade busca padronizar o comportamento sexual, assim como os desejos corporais, de acordo com o que está socialmente estabelecido, legalizando as práticas sexuais apenas a pessoas de sexo oposto e o que foge às regras é fadado à exclusão social e reprovação das condutas sexuais, traçando um perfil de interesses sexuais pelo sexo oposto, justificado pelo fator reprodutivo.

O termo heteronormatividade, é então compreendido e problematizado como um padrão de sexualidade que regula o modo como às sociedades ocidentais estão organizadas. Trata-se, portanto, de um significado que exerce o poder de ratificar, na cultura, a compreensão de que a norma e o normal são as relações existentes entre pessoas de sexos diferentes. Os transgressores da norma heteronormativa assumem outras formas de sexualidade e de gênero. Os sujeitos que escapam desafiam o instituído demonstrando que a esperada relação gênero-sexo-sexualidade não pode ser entendida como linear e natural.

Assim sendo, os desviantes dos padrões heteronormativos mudaram de sexo e gênero? Para que se possa elucidar com mais clareza essa questão, é importante salientar o conceito de sexo dado pelo Dicionário Aurélio: "1 Diferença física ou conformação especial que distingue o macho da fêmea", ou ainda, "2 Órgãos sexuais externos". Nota-se a partir dessa classificação que o conceito do termo sexo ainda se restringe a fatores biológicos, ao contrário do gênero que "é uma identidade socialmente construída, a qual os indivíduos se conformam em maior ou menor grau” (CHOERI 
2004 p. 53). Embora Raul Choeri relacione o gênero ao sexo, afirma haver distinção clara entre gênero e sexo, principalmente quanto à construção social.

O gênero, embora ligado ao sexo, não lhe é idêntico, mas construído socialmente, a partir das diferenças percebidas entre os sexos e de comportamentos coletivamente determinados, engendrados e reproduzidos no interior das instituições sociais, como a Família, a Escola e a Igreja. É também o primeiro modo de dar significado às relações de poder (CHOERI, 2004, p.53).

Já Judith Butler provoca uma fragilização ao sistema hegemônico que regia a premissa na qual se origina a distinção sexo/gênero, partindo do pressuposto de que o sexo obedece a leis biológicas e o gênero é construído. O que Butler afirmou foi que, "nesse caso, não a biologia, mas a cultura se torna o destino" (BUTLER, 1990, p. 26).

Judith Butler avança ainda mais em suas contestações quando revela a possibilidade de nunca ter havido distinção entre sexo e gênero, indicando que o sexo não obedece ao sistema biologicista, mas que também é de caráter discursivo e tão culturalmente construído como o gênero:

Se o caráter imutável do sexo é contestável, talvez o próprio construto chamado 'sexo' seja tão culturalmente construído quanto o gênero; a rigor, talvez o sexo sempre tenha sido o gênero, de tal forma que a distinção entre sexo e gênero revela-se absolutamente nenhuma (BUTLER, 2003, p. 25).

Butler afirma ainda que, o fator mais importante, é ser reconhecível e não necessariamente ser reconhecido/a, sendo os parâmetros desse reconhecimento convencionais, ou seja, pela matriz heterossexual, já que os sujeitos são reconhecíveis, primeiramente, de acordo com seu gênero, masculino ou feminino. A heteronormatividade determina "a grade de inteligibilidade cultural por meio da qual os corpos, gêneros e desejos são naturalizados" (BUTLER, 2005, p. 29).

A heteronormatividade tende a reprovar, em todo seu conceito, as práticas homossexuais, deixando os transgressores dessa norma, propícios ao processo de estigmatização social, pois a partir do momento em que fogem do padrão, tornam-se desacreditados e condenados por fugir aos moldes comportamentais e sociais no que diz respeito ao sexo, a sexualidade, ao gênero e aos preceitos sociais.

Assim, a heteronormatividade acabou atribuindo estigmas a todas as demais manifestações de sexualidade e afeto, sendo as principais consequências das estigmatizações, no que se refere ao campo da saúde, a exclusão dos usuários que não se encaixam nos padrões estabelecidos pela norma e, ainda, os diferentes tipos de violências praticados por diversos segmentos sociais, inclusive profissionais da área da saúde. 
O termo grego "estigma" foi criado para determinar a identidade social e teve como primeiros usuários, pessoas escravas, criminosas ou traidoras, que recebiam sinais feitos por cortes ou fogo, com a finalidade de evidenciar o caráter ou feito extraordinário em desacordo aos preceitos e princípios morais da época. Os que possuíam tal sinal cravado em seu corpo deveriam ser evitados e excluído do campo social, estando o mesmo impedido de frequentar com liberdade, locais públicos.

O estigma é evidenciado na diferenciação de um ou mais fatores, biológicos ou sociais, que leva a inferiorização em relação ao outro, influenciando de forma negativa nas relações humanas dentro de uma sociedade onde o politicamente correto e moral possuem padrões predestinados. Aurélio (2010) define estigma como "1 marca, cicatriz perdurável" e ainda como "2 Marca infamante feita com ferrete", o que remete ao significado grego, já que descreve as práticas referente a Grécia Antiga.

Só na década de 60 do século XX, a partir do livro Estigmas: notas sobre a manipulação da identidade deteriorada (1975), Ervin Goffman constitui a socidade como participante no processo de estigmatização. Goffman aborda que o estigma surge enquanto acontece o contato com o estranho, quando acontece tambem a categorização do sujeito em uma espécie menos desejavel: "Assim deixamos de considerá-la criatura comum e total, reduzindo-a a uma pessoa estragada e diminuída" (GOFFMAN, 1975, p. 12).

Assim, só a partir dos estudos de Goffman, as pesquisas acerca do tema "estigma" foram surgindo, inclusive, repetidas demonstrações do impacto negativo sobre a vida das pessoas estigmatizadas (LINK; PHELAN, 2001). Goffman delimita dois sujeitos físicos na discussão e conceito de estigma, os estigmatizados e os normais (termo utilizado para caracterizar as pessoas que estigmatizam).

Dessa forma, partindo do pressuposto instituído por Goffman, de que o estigma é um processo constituído socialmente, a relações sociais cotidianas estabelecem ambientes, propiciando o relacionamento entre pessoas já determinadas de acordo o perfil traçado por um grupo fechado compostos de características aceitas em comum. Portanto, um novo integrante, ao ingressar em um meio social, estará sujeito a avaliação, sendo aprovado ou não socialmente, tal aceitação dependerá dos preceitos determinados pelo grupo que estigmatiza (GOFFMAN, 1975).

Essas exigências e normas impostas pelo grupo que estigmatiza se transformam em "expectativas normativas, em exigências apresentadas de modo rigoroso" 
(GOFFMAN, 1975, p. 12). No que tange as pré concepções criadas pelos normais para categorizar os ingressos no meio social em que eles estão inseridos, para Goffman, esses critérios de inclusão determinados são ignorados e despercebidos pelos que estigmatizam, até o aparecimento de uma situação em que evidência o processo de estigmatização por eles praticado e construído:

Assim, Goffman responsabiliza a sociedade pelo estabelecimento de meios para categorizar as pessoas, incluindo "o total de atributos considerados como comuns e naturais para os membros de cada uma dessas categorias" (GOFFMAN, 1975 p.12).

Goffman (1975) traçou duas identidades para as pessoas estigmatizadas: A identidade real e a identidade virtual. $\mathrm{Na}$ identidade real, o conjunto de categorias e características para estigmatização são evidentes e provados, já na identidade virtual, o conjunto de categorias e atributos apresentados são moldados pelo contato com o meio social estranho, agindo assim de acordo as normas exigidas pelo meio.

O processo de estigmatização varia de acordo a evidência e a exposição dos atributos do estigmatizado. Goffman (1975) divide em dois grupos de indivíduos: o desacreditado, para definir o grupo de indivíduos que além de possuírem atributos distintos do meio social estranho, deixam ser visíveis e facilmente perceptíveis, já o termo desacreditável, para pessoas que apesar de possuir as características distintas do grupo social, não demonstram, assim escondem seus atributos para que não sejam percebidas pelo grupo.

O processo de estigmatização não está atrelado ao fato da existência do atributo, mas pela incoerência entre a característica e as ideias, conceitos ou modelos determinados socialmente. O processo de estigmatização se caracteriza quando os estereótipos criados pelos que estigmatizam são diferentes das características de um determinado individuo, "o termo estigma, portanto, será usado em referência a um atributo profundamente depreciativo" (GOFFMAN, 1975, p.13).

Goffman (1975) acredita que o processo de estigma pode ocorrer justificado em três circunstâncias: abominação do corpo, culpas de caráter individual e estigmas tribais de raça, nação e religião. As deformidades físicas, desonestidade e intolerância religiosas, são exemplos clássicos das circunstâncias citadas por Goffman.

Assim, o atributo de um determinado indivíduo, rejeitado em um meio social estranho, sobrepõe todos os outros atributos, sejam esses outros, aceitos ou não, sendo assim, o estigmatizado pode perde grandes oportunidades sociais ao não ser aceito em 
um meio, e, portanto, a sociedade também destrói a possibilidade de inserção de um novo indivíduo que contribuiria com o meio, assim, podemos inferir que o estigma é prejudicial a todas as partes envolvidas. Assim, torna-se lamentável o processo de estigmatização, pois "um indivíduo que poderia ser facilmente recebido na relação social quotidiana possui um traço que se pode impor atenção e afastar aqueles que ele encontra, destruindo a possibilidade de atenção para outros atributos seus" (GOFFMAN, 1975 p.14).

Tanto as práticas de heteronormatividade quanto as de estigmatização desembocam no processo de homofobia, pois "desempenha um papel determinante no que diz respeito a uma forma de inferiorização, consequência direta da hierarquia das sexualidades" (BORRILLO, 2001, p.15).

Ainlay, Coleman e Becker (1986) acreditam que os atributos pelos quais o indivíduo é estigmatizado podem ser alterados de acordo aos contextos sociais, de forma que o grau de intensidade do estigma também varia de acordo a época e o lugar em que se firma o processo de estigmatização.

De acordo localização realizada por Byrne Fone (2000), o ano de 1960 é marcado o uso popular da categoria homofobia no continente norte americano e só em 1971 o primeiro artigo científico sobre homofobia é publicado por K. T. Smith, intitulado "Homophobia: A Tentative Personality Profile". Categorizado no campo da Psicologia, o artigo levantou duas hipóteses, que mesmo não sendo cientificamente comprovadas na conclusão do trabalho, norteiam o conceito principal do senso comum até os dias de hoje, onde a existência de um certo tipo de personalidade violenta é associada a duas questões majoritárias: (1) aversão de permanência próximo a uma pessoa homossexual e (2) ódio extremo ou reações de medo direcionadas às pessoas homossexuais.

Mas é no ano 2000 que o termo ganha força com a publicação de Byrne Fone, o qual se tornou referência sobre o tema homofobia. Publicado nos Estados Unidos o artigo "Homofobia: uma história", Fone (2000) explora os fatos históricos das situações de violências ligadas a homossexualidades ao longo de diversos períodos históricos, para Fone:

[Ao longo da história] a homofobia tomou várias formas e emergiu de várias fontes. Inventada, fomentada, e suportada por diferentes agências da sociedade - religião, governo, justiça e ciência - ela tende a irromper em maior grau quando as pessoas imaginam uma ameaça aos papéis de gênero, a doutrina religiosa ou do estado e sociedade, ou até mesmo quando desestabiliza a segurança sexual e saúde do indivíduo (Fone, 2000 p. 6-7). 
Porém, só em outro artigo intitulado "Homofobia", publicado na Europa, por Daniel Borrillo (2001), criou-se um conceito mais generalista a partir do campo do Direito, dos movimentos sociais e dos Estudos Lésbicos e Gays. Foram vários os termos utilizados ao longo do tempo para classificar os desejos e relações entre pessoas do mesmo sexo: "Crime abominável, amor pecaminoso, tendência perversa, prática infame, paixão abjeta, pecado contra a natureza, vício de Sodoma” (BORRILLO 2009, p. 15), sendo os homossexuais taxados pela sociedade como bizarros e estranhos, evidenciando o processo de estigmatização histórica da população LGBT.

$\mathrm{O}$ autor divide a homofobia em duas esferas, uma geral e uma específica. $\mathrm{Na}$ homofobia geral, ocorre a discriminação de pessoas em razão de seu sexo, mas principalmente pelo gênero, "Essa forma de homofobia pode, então ser definida como a discriminação de indivíduos que demonstram, ou a quem se atribuem, certas qualidades (ou defeitos) tradicionalmente considerados do outro sexo" (BORRILLO, 2009 p. 22). Já a homofobia específica, se apresenta como uma forma de intolerância restrita a gays e lésbicas.

A homofobia também é definida por Borrillo (2009) como sendo processo da estigmatização, seja por repulsa ou violência, das relações sensíveis entre homens, particularmente quando esses homens são apontados como homossexuais ou se afirmam como tais, assim como as mulheres que não correspondem à feminilidade cobrada pelo meio social.

No Brasil, o conceito de homofobia tem sido bastante abordado por movimentos LGBT e os Estudos de Gênero e feminismos. No âmbito das primeiras políticas públicas brasileiras, o termo homofobia foi categorizado como um tipo específico de violência letal cuja causa mortis era a orientação sexual do indivíduo (MOTT, 2001). Em 2003 é lançada uma política específica de combate à homofobia, quando então a Subsecretaria de Direitos Humanos da Secretaria Geral da Presidência da República alegou que:

\footnotetext{
"a violência letal contra homossexuais, mais especificamente contra travestis e transgêneros é, sem dúvida, uma das faces mais trágicas da discriminação por orientação sexual, ou homofobia, no Brasil" (ANEXO A).
}

A homofobia está diretamente relacionada ao estigma, principalmente no que diz respeito à homofobia internalizada. Goffman (1975) sugere que a homofobia internalizada é o auto-ódio que decorre do facto de se ser uma pessoa socialmente estigmatizada. Ainda outro autor, Meyer (2003), descreve a homofobia internalizada 
como "a consciencialização do estigma que rodeia a homossexualidade, levando à vivência de sentimentos extremamente negativos; vergonha e segredo, silêncio e autoconsciência, um grande sentido de diferença - e de peculiaridade - invade a consciência”.

Os preconceitos existentes na sociedade em grande medida parece adotar vivências clandestinas quanto à sexualidade, podendo-se supor que há um silêncio envolvendo vários de seus sujeitos. Esse silêncio nada mais é que a representação desse preconceito que se refere a "atitudes injustas e negativas a um grupo ou a uma pessoa" (PEREIRA, 2002, p. 77). Relativo à homofobia, ainda se pode acrescentar sobre seu conceito que:

A palavra "homofobia" designa dois aspectos de uma mesma realidade: uma dimensão pessoal de natureza afetiva, que se manifesta pela rejeição aos homossexuais, e uma dimensão cultural de natureza cognitiva, na qual o objeto da rejeição não é o indivíduo homossexual, mas a homossexualidade como fenômeno psicológico e social. (BORRILLO, 2009, p. 19).

Mott (2005) lamenta que mesmo depois de mais de cinquenta anos da Declaração Universal dos Direitos Humanos, os movimentos homossexuais ainda tenham a denunciar tanta ilegalidade relacionada às práticas homofóbicas, já que por exemplo, "a cada dois dias, uma pessoa homossexual continua sendo brutalmente assassinada no Brasil, vítima da homofobia” (MOTT, 2005 p. 101).

A homofobia é assim um símbolo de um sentimento negativo da população homossexual e surge quando em um determinado período da humanidade, a homossexualidade passou a ser vista como algo que remetesse erro ou anormalidade, tornando-se, portanto, motivo de descriminação.

Os valores religiosos talvez seja o marco para o inicio do processo do surgimento da homofobia, categorizando o praticante de atividades homoeróticas como pecador e excluído do convívio social. Porém a homofobia toma outros campos, no século XX a homossexualidade é incluída divisão das doenças mentais e com isso, surgem clinicas de tratamento para esses "doentes" (HEREK, 2004).

O termo homofobia dá origem a outros novos termos, como: lesbofobia, bifobia, transfobia, efeminofobia, heterofobia e mais tarde SIDA-fobia (HEREK, 2004). Essas barreiras provocam prejuízos em diversos aspectos a população LGBT, principalmente quando os impedem de viver confortavelmente com sua identidade sexual.

A muito tempo a homossexualidade deixa de ser considerada como um desequilíbrio mental, porém muitos profissionais da área da saúde ainda consideram 
essa identidade sexual como uma desordem mental. Harrisson (1996) evidenciou em sua pesquisa que $89 \%$ de pessoas pertencentes ao serviço de saúde português apresentam reações negativas quando então o paciente se identificava como gay ou lésbica. Esses comportamentos negativos variavam entre embaraço, rejeição direta, exposição de hostilidade, ou até mesmo excessiva curiosidade.

Assim, nem só nos espaços de saúde a homofobia ainda vigora, mas também nos espaços educativos, causando prejuízos imensuráveis. Lionço e Diniz (2009) aponta a solidão como uma consequência marcante da homofobia, alegando que o recolhimento, a impossibilidade de trocar experiências ou até mesmo a exclusão do grupo escolar refletem de forma negativa na meta educacional do homossexual. Esses fatos são ainda mais negativos no que diz respeito a travestis e transexuais, pois:

\begin{abstract}
"são especialmente vulneráveis à exclusão do espaço escolar, o que repercute negativamente em suas oportunidades sociais e profissionais, tendo como consequência o reforço de estereótipos que os estigmatizam: é o caso da prostituição, que, embora associada em termos essencialistas à condição dessas pessoas, resulta da exclusão escolar e familiar. Travestis e transexuais passam a viver vulneráveis à opressão de oportunistas, já que escola e família se eximem da responsabilidade do acolhimento e da promoção de formas de convívio mais solidárias. A escola, porém, deve trabalhar possibilidades de pertencimento, isto é, a inclusão de todos num mesmo espaço de sociabilidade.
\end{abstract}

Borrillo (2009) elucida a acentuada mudança ocorrida na maneira como a hostilidade para com a população LGBT vinha sendo problematizada, evidenciando uma modificação no foco do estudo, que deixa de avaliar o comportamento homossexual, voltando-se nos dias atuais para as razões pelas quais os desejos e relações homoafetivas foram consideradas desviantes no passado. Esse deslocamento do objeto de análise a respeito de homofobia acaba por produzir transformações epistemológicas e política:

Epistemológica porque não se trata exatamente de conhecer ou compreender a origem e o funcionamento da homossexualidade, mas sim de analisar a hostilidade provocada por essa forma específica de orientação sexual. Política porque não é mais a questão homossexual, mas a homofobia que merece, a partir de agora, uma problematização particular (BORRILLO, 2009 p.16).

Borrillo (2009) também afirma que essa normatização da heterossexualidade mantem-se mais como uma reprodução de ordem social que um mecanismo de reprodução da espécie. A homofobia passa então a ser um mecanismo de defender e proteger a fronteira sexual e dos gêneros. Assim, explica-se a razão pela qual os homossexuais não são as únicas vítimas da violência homofóbica (BORRILLO, 2009) isolando assim todos aqueles transgressores dos padrões, como travestis, transexuais, 
bissexuais, mulheres heterossexuais que possuem traços fortes em sua personalidade, homens heterossexuais delicados ou sensíveis.

A homofobia é considerada para como um fenômeno complexo e delicado. Assim, podemos evidenciá-lo desde piadas que ridicularizam a relação ou o sujeito homossexual ou até mesmo em violência física e morte. Assim, o serviço de saúde deve isentar em suas práticas diárias em todas as hipóteses desses tipos de violência para que o indivíduo ao procurar os serviços, encontre proteção integral de sua saúde.

Os números de violências com morte ocorridas no Brasil nos últimos anos são assustadores. O Grupo Gay da Bahia é a mais antiga associação de defesa dos direitos humanos dos homossexuais no Brasil, fundado em 1980 pelo professor titular de antropologia da Universidade Federal da Bahia, Luiz Mott, e anualmente divulga relatórios precisos do número de mortes por ano da população LGBT.

Embora as informações e conceituação do termo homofobia tenha maior circulação nos últimos anos, os números apontam que há uma carência exorbitante de medidas que diminuam ou erradique as mortes da população LGBT causadas pela homofobia.

Segundo relatório anual publicado em 2013 pelo Grupo Gay da Bahia (GGB), em 2012 foram registradas 388 mortes da população LGBT no Brasil, quando comparado ao ano anterior, há um aumento de $27 \%$ em número de assassinatos (266 mortes) e em uma escala comparativa maior, nos últimos sete anos o número de mortes cresceu em $177 \%$.

Dentre a população LGBT vítima no ano de 2012, o maior número de homicídios foi de gays (56\%), seguido de travestis (37\%), lésbicas (5\%) e bissexuais (1\%). Esses números mantém, em 2012, o Brasil na posição de primeiro lugar em número de assassinatos homofóbicos no mundo. O GGB atribui o alto índice de assassinato e a acentuada massa homofóbica no Brasil a irresponsabilidade das esferas de governo por não garantir a segurança da comunidade LGBT, alegando que "a falta de políticas públicas dirigidas às minorias sexuais mancha de sangue as mãos de nossas autoridades" (GGB, 2013, p 2).

São Paulo em 2012 liderou o número de assassinatos (45 mortes), mas em termos relativos Alagoas se apresentou como o estado mais perigoso a população LGBT em 2012, com 5,6 homicídios para cada milhão de habitantes, seguido do estado da Paraíba, com 4,9 crimes por milhão de habitantes e em terceiro lugar o estado do Piauí, 4,7 crimes por milhão de habitantes (GGB, 2013). 
A faixa etária que apresenta maior risco de assassinato, 57\%, situa-se entre 2040 anos. O padrão predominante é o gay ser assassinado dentro de sua residência, com armas brancas ou objetos domésticos, enquanto as travestis e transexuais são mortas na pista, a tiros (GGB, 2013).

Segundo o relatório referente ao ano de 2012 do Grupo Gay da Bahia, a cidade de Teresina foi constatada como a capital que oferecia mais riscos a população LGBT, pois apresentou o maior índice de risco relativo, 15,6 por milhão de habitantes (GGB, 2013).

No ano de 2013, ocorreram 312 assassinatos e embora tenha decrescido em 7,7\% em relação ao ano anterior, os números não são menos preocupantes em proporção quando ocorre um assassinato a cada 28 horas. Isso faz com que o Brasil continue em primeiro em crimes homo/transfóbicos e, no Brasil, o nordeste mantém invicto na posição de região demográfica mais violenta e homicida de pessoas LGBT.

Dentre os grupos mais atingidos pelos crimes de ódio resultantes em homicídios no ano de 2013, não houve alteração na ordem em relação a 2012, os gays (59\%) foram os mais vitimados pelos crimes de homicídio, seguidos por travestis (35\%), lésbicas $(4 \%)$ e bissexuais $(1 \%)$. Em termos relativos o estado mais homofóbico foi Roraima com 6,5 homicídios por milhão de habitantes, seguido pelo estado do Mato Grosso 4,71 mortes por milhão e o Rio Grande do Norte com 4,45 mortes por milhão de habitantes (GGB, 2014).

A idade de maior risco mantém-se entre 20-40 anos, mantendo também o perfil do crime, tendo a residência como local do crime com armas brancas ou objetos domésticos, enquanto as travestis e transexuais são mortas na pista, a tiros (GGB, 2014). A capital piauiense que ocupava o primeiro lugar em números relativos de assassinatos passa a ocupar o quinto lugar, com 5,98 mortes por milhão de habitantes.

O aumento registrado no ano de 2014, torna ainda mais preocupante a proporção dos crimes, passando a apresentar uma morte a cada vinte e sete horas, mantendo o Brasil no topo mundial em números de trans/homicídios. O grau de risco em relação aos grupos se manteve, sendo gays mais vulneráveis aos crimes de homicídios, seguidos dos travestis, lésbicas e bissexuais (GGB, 2015).

Dentre os estados brasileiros, João Pessoa foi o mais homofóbicos, registrando 4,56 mortes por milhão de habitantes e o Piauí passa a ocupar o segundo lugar com 4,07 mortes/milhão, suas respectivas capitais foram consideradas, também, as mais perigosas 
do Brasil, registrando na Paraíba 15,37 e em Teresina 11,90 mortes por milhão de habitantes (GGB, 2015).

Durante décadas, o nordeste foi o estado mais incidente para os crimes homofóbicos, em 2014 a realidade muda, passando o Centro-Oeste como a região demográfica com maior risco da população LGBT ser violentada e morta. A ordem dos grupos vitimados se mantém, sendo os gays (50\%) com maior risco, seguidos por travestis $(41 \%)$, lésbicas $(4 \%)$ e bissexuais $(0,9 \%)$.

Além de haver alteração na região mais incidente, ocorre também em 2014 uma mudança no perfil etário das vitimas de violência e morte, passando de 20-40 nos anos anteriores, para 20-60, aumentando o número de vítimas com maior idade. As alterações permeiam também a causa mortis, já que sempre eram classificados nos anos anteriores como crimes de ódio, sendo então reclassificado, devido a natureza dos crimes, como crimes de "ódio com requintes de crueldade", já que as armas brancas e objetos domésticos perdem espaço para as armas de fogo (GGB, 2015).

Assim, podemos observar a insegurança da população LGBT no Brasil tendo em vista os índices apresentados nesses últimos três anos. A constância no número de mortes para o pesquisador Luiz Mott (2011) acontece devido a falhas no poder público, alegando que "A certeza da impunidade e o estereótipo do gay como fraco, indefeso, estimulam a ação dos assassinos" (MOTT, 2011, p.3).

Quer se trate de uma escolha de vida sexual, quer se trate de uma característica estrutural do desejo erótico por pessoas do mesmo sexo, a homossexualidade deve ser considerada tão legítima quanto à heterossexualidade. De fato, ela não é mais que a simples manifestação do pluralismo sexual, uma variante constante e regular da sexualidade humana. Na condição de atos consentidos entre adultos, os comportamentos homoeróticos devem ser protegidos como qualquer outra manifestação da vida privada.

Como um atributo da personalidade, a homossexualidade deve permanecer fora do interesse interventor das instituições. Tal como a cor da pele, a opção religiosa ou a origem étnica, ela deve ser considerada um dado não pertinente na construção política do cidadão e na qualificação do sujeito de direitos. Contudo, embora o exercício de uma prerrogativa ou a fruição de um direito não sejam mais subordinados ao pertencimento a um ou outro sexo, religião, política ou classe social, a homossexualidade permanece como um obstáculo ao pleno gozo de direitos. (BORRILLO, 2009, p 16 e 17). 
Assim, além dos impactos diretos por lesões e mortalidade relacionados à homofobia, os estigmas e discriminações tem sido tratados em saúde pública como determinantes de saúde que influenciam tanto no acesso à atenção, como na qualidade da atenção prestada a população LGBT.

\section{Diversidade sexual e ações de saúde}

A criação da Política Nacional de Saúde Integral da População de Lésbicas, Gays, Bissexuais, Travestis e Transexuais (LGBT), pela Portaria $n^{\circ} 2.836$, de $1^{\circ}$ de dezembro de 2011, denota, sem dúvidas, um grande avanço no que confere à saúde de uma população em situação de vulnerabilidade, assim como prova a crescente obtenção de direitos por parte dessa comunidade e o inegável aumento da visibilidade da mesma. Porém não foi uma trajetória fácil e recente, embora só em 2004 os avanços notórios, no que diz respeito às políticas de estado, começaram a ser apresentados à sociedade.

Desde o final da década de 70, quando surgiram os primeiros movimentos sociais em defesa de grupos específicos e liberdade sexual, que cidadãos homossexuais buscavam usufruir de direitos igualitários, inclusive os que permeiam o campo da saúde, mas só conseguiram apoio do governo brasileiro no início dos anos 80, mas pelo advento do HIV/AIDS estar fortemente relacionado às praticas sexuais de gays e travestis, em específico (BRASIL, 2011).

Essas lutas perduraram por décadas, com tímidos progressos e com índices de violências cada vez maiores em razão da orientação sexual e da identidade de gênero (LIONÇO, 2008). Realidade cruel, perversa e grave quanto à existência de preconceito e discriminação em setores da sociedade civil que, até hoje se faz presente, levando esses sujeitos às torturas e morte, mesmo em instituições sociais que envolvem mediações das políticas públicas e direitos humanos (DUARTE, 2014).

Como um produto dessas densas relações de saber e poder da sociedade e através do movimento LGBT, as questões de gênero ganharam visibilidade no cenário mundial e o Estado passou a ser pressionado para garantir direitos iguais e efetivar políticas públicas que visem diminuir a discriminação e o preconceito contra essa população. Em 2004 começam a surgir tímidos resultados na esfera federal de lutas incansáveis de gerações que morreram sem mesmo desfrutarem das constantes "batalhas" que travaram para a garantia de seus direitos. Como resposta desse percurso 
histórico, o governo federal lançou o Programa Brasil sem Homofobia (CARDOSO; FERRO, 2012).

Esse programa buscou demandas específicas de vulnerabilidades, levando em consideração sujeitos propensos e submetidos a diversas formas de preconceito, discriminação e marginalização. Duarte (2014) inclui essas vulnerabilidades nos territórios dos serviços técnico-operacionais de saúde nos seus variados níveis de atenção e cuidado, alegando ser uma herança histórica, quando, por exemplo, existiram diversas resistências dos trabalhadores da saúde no que diz respeito aos atendimentos e procedimentos técnicos com LGBT infectados pelo HIV/AIDS, batizando a patologia como "peste gay".

Para que os objetivos de combater a violência e discriminação contra a população LGBT e para promoção à cidadania homossexual fossem alcançados, elencaram-se cinquenta e três ações divididas em onze áreas, com envolvimento de oito secretarias e ministérios, e desse conjunto de ações, três se destacam como sendo para saúde LGBT (BRASIL, 2004). Essas ações dizem respeito ao apoio a implementação de condições para produção de conhecimento científico sobre saúde e outros aspectos LGBT, apoiando os investimentos na formação, capacitação e sensibilização de profissionais de saúde para garantia de acesso igualitário e acolhimento as especificidades de demandas de saúde (RAMOS; CARRARA, 2006).

Segundo Lionço (2008), a principal dessas evoluções foi a formalização do Comitê Técnico de Saúde da População de Gays, Lésbicas, Transgêneros e Bissexuais, do Ministério da Saúde, com o objetivo de estruturar uma Política Nacional de Saúde para essa população. As outras duas reportam-se à produção de conhecimentos sobre saúde da população LGBT e à capacitação de profissionais de saúde para garantir o atendimento igualitário e correto.

O lançamento da Política Nacional de Atenção Integral à Saúde da Mulher, com a finalidade de reconhecer a necessidade de atenção no atendimento à saúde, às particularidades de diferenciados segmentos de mulheres, especialmente as mulheres lésbicas, que foram incluídas na política como pertencentes a uma fatia com necessidades diferenciadas de atenção e cuidado assistencial, o que denota uma preocupação por parte da esfera pública no atendimento as especificidades desse segmento (BARBOSA; FACCHINI, 2009). 
Outros avanços estratégicos foram sendo alcançados, prova disso é a Portaria GM nº 426 de 22 de março de 2005 que institui no Sistema Único de Saúde, a Política Nacional de Atenção Integral em Reprodução Humana Assistida e a Portaria GM nº 675 de 30 de março de 2006 que aprova a Carta de Direitos dos Usuários da Saúde e consolida os direitos e deveres do exercício da saúde em todo Brasil, nela, afirma-se que todas as pessoas devem ser atendidas sem discriminação por orientação sexual e identidade de gênero (LIONÇO, 2008).

A representação LGBT também esteve presente na $13^{\text {a }}$ Conferência Nacional de Saúde, realizada em 2007, quando a proposta era desenvolver e amadurecer a sociedade brasileira no que diz respeito às discussões e deliberações democráticas sobre as políticas públicas de saúde no país, o seu relatório final traz propostas que tratam de forma específica de questões de saúde do segmento LGBT (MELO et al., 2012).

Outro grande progresso para toda população LGBT nas políticas públicas de saúde acontece ainda em 2007, quando é lançado pelo Ministério da Saúde o Plano Integrado de Enfrentamento de Epidemias de AIDS e outras DSTs. Além de contemplar o público gay, bissexuais (classificado como homens que fazem sexo com outros homens) e travestis, engloba em sua proposta mulheres lésbicas, bissexuais e transexuais, fruto do enfrentamento da feminilização da epidemia de AIDS e outras DSTs, já que eram consideradas endêmicas apenas em homens gays, bissexuais e travestis. O plano buscou o enfrentamento de epidemias por meio da redução de vulnerabilidades, estabelecendo política de prevenção, promoção e atenção integral à saúde (BARBOSA; FACCHINI, 2009).

O ano de 2008, além de ser marcado pelo lançamento da versão preliminar da Política Nacional de Saúde Integral de Gays, Lésbicas, Bissexuais, Travestis e Transexuais, acontece também a I Conferência Nacional LGBT, que objetivou explicitar as demandas do movimento LGBT brasileiro, apresentando como produto, 559 propostas aprovadas em plenária final, das quais, 167 dizem respeito ao campo da saúde (CARDOSO, FERRO, 2012). Em 18 de agosto é então publicada a Portaria GM n ${ }^{\circ}$ 1.707 que institui no âmbito do Sistema Único de Saúde o processo transexualizador, a ser implantada nas unidades federativas, respeitando as competências das três esferas de gestão, trazendo uma (r)evolução no âmbito político (BRASIL, 2008; VALADÂO, GOMES, 2011).

O Plano Nacional de Promoção da Cidadania e Direitos Humanos de Gays, Lésbicas, Bissexuais, Travestis e Transexuais, sistematizou, em 2009, propostas 
aprovadas na I Conferência Nacional LGBT e estabeleceu 166 estratégias de ações que integram o plano, sendo 48 focadas à saúde LGBT (BRASIL, 2009; MELO et. al., 2012).

Ainda em 2009, o III Programa Nacional de Direitos Humanos, com intuito de fortalecer a garantia e os instrumentos de participação social, o caráter transversal dos Direitos Humanos e a construção de mecanismos de avaliação e monitoramento de sua efetivação, foi lançado. A atenção à saúde da população LGBT também foi contemplada, quando foi incluída no conjunto das ações propostas para diversos segmentos marginalizados e subalternados (DUARTE, 2014).

O modelo de construção da identidade homossexual vem evoluindo constantemente, sendo influenciado também pelos modelos pré-existentes, conduzindo relações desses modelos ao campo da saúde. No entanto, seus resultados chamam a atenção para a importância dos determinantes socioculturais que ainda continuam a influenciar o bem-estar dos indivíduos. A sexualidade humana e, particularmente, o conceito de identidade sexual, construídos e alterados continuamente, já que são os condicionantes de ordem cultural que determinam as diferentes interações que, logo, influenciam, diretamente, o modo como as pessoas (des)constroem a sua identidade.

Mesmo frente às lutas LGBT, que se fortaleciam, imperou o silêncio associado a grande lacuna no campo das políticas públicas; o país então se desenvolvia, e associado a isso, os números na violência também aumentavam, tornando a equidade um princípio bem distante da realidade social da população LGBT, pois, grupos sociais distintos, como negros, índios, mulheres, crianças, idosos e as pessoas do grupo LGBT, podem ter necessidades de saúde diferenciadas, implicando demandas por ações governamentais também diferenciadas (MELO et. al., 2011).

Porém, mesmo frente aos empasses sofridos pela população LGBT, é importante destacar que importantes estudos, realizados nos últimos dez anos, foram fundamentais para o fortalecimento e amadurecimento das discussões voltadas para o acesso e as condições de saúde da população LGBT. Pereira (2005), por exemplo, buscou, em um momento de complicado da discussão, explicar como se constrói a identidade homossexual e compreender os seus determinantes para tal não acontecer e afirmou que para uma boa construção da identidade sexual, faz-se necessário a inclusão de determinantes, tais como: "apoio dos amigos", "autoestima", "qualidade de relacionamentos", dentre outros. 
O hiato na produção acadêmica sobre saúde LGBT é encerrado por Tatiana Lionço (2008) que evolui nas discussões que permeiam a problematização sobre a pertinência de uma política específica de saúde para a população LGBT e chega a conclusão que o desafio da construção de uma política de atenção integral à saúde dessa população implica a complexificação e alargamento do que se compreende por direitos sexuais e reprodutivos para a efetiva promoção da equidade e universalidade do acesso aos bens e serviços.

Um ano depois, Barbosa e Facchini (2009) dá um grande passo nas discussões científicas quanto ao cuidado de saúde das mulheres lésbicas ao investigar a relação entre adoção de cuidados à saúde entre mulheres que fazem sexo com mulheres e as representações relativas a gênero, sexualidade e ao corpo, evidenciam que o receio e a ideia de preconceito estão associados à decisão de relatar ou não ao profissional as práticas e preferências eróticas, e para tanto, se faz necessário discutir a questão do acesso a cuidados ginecológicos entre mulheres lésbicas, levando em conta a diversidade dessas mulheres.

O avanço nas discussões da saúde das lésbicas e bissexuais é reforçado por estudos realizados por Valadão e Gomes (2011) que ao analisar os modelos que podem explicar a invisibilidade de lésbicas e mulheres bissexuais na área da assistência integral à saúde da mulher, concluem que as lésbicas e mulheres bissexuais não têm apoio por parte dos profissionais de saúde para verbalizar suas orientações sexuais quando buscam assistência.

Dois grandes estudos realizados por Melo (2011 e 2012) reforçam a importância do reconhecimento da população LGBT como vítimas de violências e processos históricos de exclusão, inclusive nos serviços de saúde. Ao analisar, em 2011, as políticas públicas de saúde voltadas à população LGBT, Melo evidencia que os princípios do Sistema Único de Saúde ainda precisam serem incluídos no atendimento para que seja possível o enfrentamento e superação da LGBTfobia, especialmente no tocante aos profissionais de saúde. Já em 2012, Melo ao refletir sobre a efetividade dos planos, programas e conferências produzidos e realizados pelo governo federal no processo de construção de políticas públicas para a população LGBT no Brasil, afirma que a inexperiência na execução de políticas transversais e intersetoriais relativas a 
gênero e direitos sexuais, bem como as carências orçamentárias ainda dificultam a qualidade da assistência e do acesso.

Cardoso e Ferro (2012) contribuem para a reflexão sobre alguns dos fatores que podem interferir de maneira substancial no processo de saúde da população LGBT, evidenciando que ainda existem distintas e diversas dificuldades e entraves gerados a partir do desconhecimento das redes de apoio e das políticas públicas por parte dos profissionais de saúde, o que implica diretamente no processo de vulnerabilidade que leva ao adoecimento da população LGBT. Recentemente, ao problematizar elementos históricos que construíram a Política Nacional De Saúde Integral LGBT, denunciam as notáveis resistências e omissões quanto à violência no contexto das singularidades dos sujeitos LGBT.

Contudo, mesmo frente às ações já produzidas nos Planos, Programas e Conferências de saúde LGBT no Brasil, a carência de uma política específica sempre se fez necessária para esses grupos, e após sua publicação, a principal dificuldade é sua práxis. No entanto, destaca-se alguns programas e políticas precursores dessa discussão, como o Programa Brasil Sem Homofobia (2004), a Carta de Direitos dos Usuários da Saúde (2006) e a Política Nacional de Saúde Integral de LGBT (2010).

Posto as diversas lacunas entre o Sistema Único de Saúde e a população LGBT, e suas evidências de que a orientação sexual e identidade de gênero são determinantes sociais de saúde, a Política LGBT teve como proposta o reconhecimento dos antecedentes sócio-históricos e culturais de iniquidades e exclusão social dos LGBT da agenda de saúde, e se propõe a ampliar os conhecimentos, habilidades e atitudes dos seus principais atores, a fim de dirimir entraves, quanto aos preconceitos e juízos de valor negativos em relação ao segmento, e reconhecer que assim como todo e qualquer cidadão brasileiro, os LGBT têm necessidades de saúde variadas e devem receber cuidados humanizados e pautados na integralidade em todos os níveis da atenção. 


\section{METODOLOGIA DA DISSERTAÇÃO}

Esta pesquisa tem por objeto o acesso e a qualidade da atenção integral prestada à população de Lésbicas, Gays, Bissexuais, Travestis e Transexuais (LGBT), no âmbito do Sistema Único de Saúde (SUS). Assume-se que esta é uma pesquisa de natureza qualitativa, por entender que a mesma circulará entre diversos movimentos e processos sócio-politico-histórico entre os sujeitos do estudo. Ou seja, os sujeitos dão significado a suas ações e construções, dentro de uma racionalidade presente nas ações humanas, no caso, as relacionadas ao processo saúde-doença-cuidado. Para Minayo (2013), na pesquisa social existe uma identidade entre sujeito e objeto, revelando um substrato comum de identidade com o investigador, tornando sujeitos e pesquisador imbricados e comprometidos numa mesma ciência. Além disso, assume-se a não neutralidade diante da implicação da visão de mundo do pesquisador em todo processo de conhecimento. Diante da realidade social observada a abordagem qualitativa permite uma aproximação à existência humana, ainda que de forma incompleta, por meio de instrumentos e teorias que demonstrem o desafio do conhecimento.

O estudo será de abrangência nacional que contemple as cinco regiões: no Norte, Pará: Belém, Santarém; Amapá: Macapá; Acre: Rio Branco. No Nordeste, Bahia: Salvador, Feira de Santana, Vitória da Conquista; Pernambuco: Recife; Paraíba: João Pessoa; Ceará: Fortaleza e Juazeiro do Norte; Piauí: Teresina, Picos. No Centro-Oeste, Mato Grosso do Sul: Campo Grande. Distrito Federal: Brasília; Ceilândia; Taguatinga; Sobradinho. Goiás: Goiânia. No Sudeste, Rio de Janeiro: Rio de Janeiro; São Paulo: São Paulo, e São José do Rio Preto; Minas Gerais: Belo Horizonte, Uberlândia; Espírito Santo: Vitória. No Sul, Paraná: Curitiba e Maringá; Rio Grande do Sul: Porto Alegre. A coleta dos dados para esta pesquisa será realizada por meio de questionário eletrônico a ser desenvolvido pelo Centro de Tecnologias Educacionais Interativas em Saúde (CENTEIAS), com questões dirigidas aos gestores do SUS.

Complementarão o estudo de campo com o uso de Entrevistas individuais semiestruturadas, a serem aplicadas com os gestores dos municípios, gerentes das Unidades Básicas de Saúde, profissionais das equipes de Saúde da Família. A pesquisa deve englobar unidades básicas de saúde, ambulatórios e serviços habilitados/credenciados (Hospital de Clínicas de Porto Alegre - Porto Alegre/RS; HUPE Hospital Universitário Pedro Ernesto - Rio de Janeiro/RJ; Fundação Faculdade 
de Medicina HCFMUSP Inst. de Psiquiatria - Fundação Faculdade de Medicina MECPAS - São Paulo/SP; Hospital das Clínicas da Universidade Federal de Goiás Goiânia/GO) e de referência (Ambulatório para Travestis e Transexuais da Universidade Federal de Uberlândia - UFU/MG e Ambulatório para Travestis e Transexuais do CRT DST/Aids de São Paulo/SP).

A presente pesquisa foi realizada na cidade de Teresina, pelo Núcleo de Estudos em Saúde Pública da Universidade Federal do Piauí sob a coordenação do Professor Dr. José Ivo dos Santos Pedrosa. Tendo em vista os índices de violências da população LGBT da capital piauiense e, tendo em vista, a percepção histórica da classe médica a respeito da condição LGBT como patológica, o presente estudo analisa apenas o discurso médico como recorte da pesquisa central desenvolvida pelo NESP-UnB. 


\section{RESULTADOS E DISCUSSÕES.}

Os resultados e discussões serão apresentados em formato de artigo.

Título: Unidades Básicas de Saúde em Teresina-PI e o acesso da população LGBT: o que pensam os médicos?

Submissão: Revista Tempus Actas de Saúde Coletiva, da Universidade de Brasília, conforme termo de submissão (ANEXO 5).

Autores: Edson Oliveira Pereira; Claudio Garcia Forte Lorenzo. 


\title{
UNIDADES BÁSICAS DE SÁUDE EM TERESINA-PI E O ACESSO DA POPULAÇÃO LGBT: O QUE PENSAM OS MÉDICOS?
}

\section{BASIC HEALTH UNITS IN TERESINA-PI AND THE ACCESS TO LGBT POPULATION: WHAT DOCTORS THINK?}

\section{UNIDADES BÁSICAS DE SALUD EN TERESINA -PI Y POBLACIÓN LGBT ACCESO: ¿QUÉ PIENSAN LOS MÉDICOS?}

Edson Oliveira Pereira- Biólogo, mestrando em Saúde Coletiva pela Universidade de Brasília (edsondirec@gmail.com); Claudio Fortes Garcia Lorenzo - Professor dos Programas de Pós Graduação em Saúde Coletiva e em Bioética da Universidade de Brasília.

\section{RESUMO}

Este estudo teve como objetivo investigar a percepção de médicos de Unidades Básicas de Saúde de Teresina, considerada uma das mais homofóbicas capitais brasileiras, sobre o acesso e qualidade da atenção à população LGBT. Trata-se de uma análise qualitativa de discurso sobre entrevistas semiestruturadas com profissionais médicos de sete unidades de saúde selecionadas por sorteio entre as 22 existentes na cidade e fundamentada no método hermenêutico-dialético. Quatro principais categorias analíticas emergiram: 1. Percepção confusa entre universalidade e equidade, 2. Patologização e percepção de anormalidade na condição, 3. Negação de barreira ao acesso e imputabilidade da ausência de procura do serviço aos próprios sujeitos, e 4. Baixa demanda do grupo LGBT ou invisibilidade da condição. Conclui-se que um dos principais desafios à implementação da política nacional de saúde dirigida a esta população continua sendo os estigmas e preconceitos incorporados nas subjetividades dos profissionais, os quais dificultam a compreensão de direitos e as razões da existência de políticas compensatórias.

PAlaVRaS CHAVE - Identidade Sexual; Políticas Públicas De Saúde; Equidade Em Saúde; Homossexualidade.

\begin{abstract}
This study aimed to investigate the perception of physicians in Basic Units of Health of Teresina, considered one of the most homophobic Brazilian capital, about access and quality of care to the LGBT population. We did a qualitative analysis of discourse on semi-structured interviews with physicians of seven health units selected by lot from among the 22 existing in the city and based on the hermeneuticdialectic method. Four key analytical categories emerged: 1.percepção confused between universality and equity, 2.patologização and perception of abnormality in the condition 3. Barrier denial of access and accountability to the lack of demand for the service to the subjects themselves, and 4. Low demand from LGBT group or invisibility of the condition. We conclude that a major challenge to the implementation of national health policy aimed at this population remains the stigmas and prejudices incorporated into
\end{abstract}


professional subjectivities, which hinder the understanding of rights and the reasons for the existence of compensatory policies.

KEY WORD- Sexual identity; Public Policy Health Care ; Equity in Health ; Homosexuality.

\section{RESUMEN}

Este estudio tuvo como objetivo investigar la percepción de médicos en Unidades Básicas de Salud de Teresina, considerada una de las capitales brasileñas más homofóbicas, sobre el acceso y la calidad de la atención a la población LGBT. Si hace un análisis cualitativo del discurso en entrevistas semiestructuradas con médicos de siete unidades de salud seleccionadas por sorteo de entre las 22 existentes en la ciudad y fundamentada en el método hermenéutico-dialéctico. Cuatro categorías analíticas clave surgieron: 1.percepção confusa entre universalidad y equidad, 2.patologisación y percepción de anormalidad en la condición 3. Negación de barrera de acceso y atribución de falta de procura por los servicios a los propios sujetos, y 4. Baja demanda del grupo LGBT o invisibilidad de la condición. La conclusión es que uno de los mayores desafíos a la aplicación de la política nacional de salud dirigida a esta población sigue siendo los estigmas y prejuicios incorporados a las subjetividades profesionales, las cuales dificultan la comprensión de los derechos y de las razones para la existencia de políticas compensatorias.

PALABRAS-CLAVE - Identidad sexual; Políticas Públicas de Salud; Equidad en Salud; Homosexualidad. 


\section{INTRODUÇÃO}

A tentativa de reivindicar os diretos ligados ao campo da saúde para a população LGBT emerge na transição do século XX para o século XXI (BARBOSA, FACCINI, 2009). As exigências iniciais ocorreram frente às diversas formas de pressão por diferentes movimentos sociais vinculados à causa LGBT, tendo como principal foco o enfrentamento da epidemia do HIV/AIDS, que no período começou a ser intitulada como "peste gay" ou "câncer gay", dada a maior incidência e prevalência naquela população, o que trouxe como consequência impactante, o reforço ao preconceito e discriminação contra o grupo social LGBT (CARRARA, 1987).

Por outro lado, essas pressões discriminatórias fortaleceram a participação dos grupos LGBT na busca pelos diretos sociais historicamente negados, inclusive no campo da saúde (BRASIL, 2010). As lutas ao longo do tempo culminaram com reconhecimento do preconceito e discriminação enquanto determinantes de saúde, e da necessidade de um planejamento de saúde que contemplasse a complexidade da oferta de atenção, dadas as condições de estigmatização e discriminação desse grupo.

Carvalho e Philippe (2013) afirmam que a ausência de um acolhimento adequado nas unidades de saúde configura um dos principais problemas enfrentados pela população LGBT. Já Sousa e cols (2009) destacam que o processo de humanização no SUS depende de mudanças sistemáticas e estratégicas que envolvem as formas de pensar e agir da comunidade, dos gestores e dos profissionais da saúde, no sentido de garantir o respeito às diferentes manifestações da sexualidade e às diversas formas de constituição familiar.

A confluência de esforços dos movimentos sociais e da produção científica brasileira levou o Ministério da Saúde à elaboração de programas e políticas públicas específicas, assim como inclusão de diretrizes relacionadas à população LGBT em outras políticas públicas de saúde. A Política Nacional de Atenção Integral da População LGBT (PNAILGBT), publicada em 2010, representou, de certa forma, um ponto culminante desse processo, uma vez que sua elaboração traz entre seus objetivos principais a redução das desigualdades relacionadas à saúde desses grupos sociais e o combate à discriminação e ao preconceito institucional enquanto obstáculos ao acesso, acolhimento e qualidade da atenção (BRASIL, 2010a). No ano seguinte, a publicação da Política Nacional de Atenção Básica, reafirmou a Estratégia de Saúde da Família (ESF) como 
principal porta de entrada do sistema de saúde e determinou que o percurso do usuário deve iniciar-se com o ato de acolher, escutar e oferecer resposta resolutiva para a maioria de seus problemas de saúde (BRASIL, 2011).

Entretanto, o alcance do cumprimento das diretrizes das políticas nos diversos níveis de complexidade da atenção não se dá pela simples elaboração e publicação de seus enunciados. Trata-se de uma tarefa complexa, uma vez que os padrões heteronormativos hegemônicos na sociedade atuam diretamente na geração e reprodução de posturas discriminatórias, as quais inevitavelmente influenciam na conduta dos profissionais que atenderão as demandas desse grupo.

A superação do problema implicará, sem dúvida, processos de formação continuada onde as questões envolvendo preconceito, sexualidade e atenção à saúde sejam trabalhadas não apenas na perspectiva cognitiva da informação e da norma, mas na perspectiva de autocompreensão subjetiva da constituição de seus próprios preconceitos e valores. É fundamental, portanto, conhecer as diversas perspectivas sobre o problema dos diversos profissionais que atuam no sistema de saúde. Em um país de dimensões continentais e estruturas sociais tão complexas como o Brasil, esses fatores podem surgir de formas mais ou menos intensa a depender do contexto sociocultural onde as unidades de saúde estejam inseridas, daí a importância de investigações que incluam estes diversos contextos.

De acordo dados do Sistema de Informação da Atenção Básica (2009), Teresina apresenta a estratégia saúde da família em praticamente todos os bairros do município, cobrindo uma população de 759.000 pessoas, o que representava 95,6\% da população geral do município; com 72 Centros de Saúde/Unidades Básicas de Saúde e 220 equipes de saúde da família, distribuídas nas áreas urbana e rural. Por outro lado, o estado do Piauí vem registrando altíssimos índices de homicídio contra a população LGBT, tendo sua capital Teresina chegado a ocupar entre 2010 e 2012, o primeiro lugar como capital que oferecia mais riscos a população LGBT; em 2013, o de quinta capital mais homofóbica do país e finalmente em 2014, a segunda posição em números de crimes de ódio envolvendo intolerância à orientação sexual, de acordo relatórios anuais do Grupo Gay da Bahia.

O presente artigo teve como objetivo principal, verificar a percepção dos profissionais médicos na rede da Atenção Básica do município de Teresina, capital 
piauiense, a respeito do acesso da população LGBT ao Sistema Único de Saúde. O estudo foi produzido a partir de um recorte da pesquisa multicêntrica coordenada pelo Núcleo de Estudos em Saúde Pública da Universidade de Brasília (Nesp/UnB) sobre acessibilidade e qualidade de atenção à população LGBT em todo território nacional.

\section{Sobre os males que assolam o acesso da população LGBT aos sistemas de saúde no Brasil.}

No que se diz respeito ao campo da saúde, o universo simbólico em torno da diversidade sexual foi primordialmente construído pela ordem médica, a qual por muito tempo identificou e classificou o segmento LGBT como portadores, em particular, de patologia mental e desvio de conduta sexual. Muitos desses sujeitos se submeteram a internações forçadas em instituições manicomiais de tratamento para portadores de transtorno mental, a fim de obterem a cura, onde foram tratados com eletrochoques, intensa medicamentalização, banhos frios, isolamento, dentre outras torturas e explícitas violações de direito aos ditos degenerados (CAPONI, 2012).

Embora o "homossexualismo", expressão utilizada à época, tenha sido extinta do manual de perturbações mentais da Associação Americana de Psiquiatria em 1973 e da lista de doenças mentais da Classificação Internacional de Doenças (CID) da Organização Mundial de Saúde (OMS), em 1985, ainda vigora uma forte relação nos ambientes conservadores da sociedade e das instituições de saúde da orientação sexual à patologização dessas pessoas, por entenderem que as relações homoafetivas fogem das condutas "naturais" e são passíveis de "correção". (MELO et. al., 2012).

Outro fator que tem sido considerado como contribuinte para construção de um universo simbólico de negatividade em relação à diversidade dos comportamentos sexuais é o uso do "fator de risco" enquanto categoria analítica do discurso epidemiológico, que segundo AYRES (1997 e 2005) produziu noções secundárias de "grupos de risco" e "práticas de risco" levando a um processo de estigmatização e discriminação de adolescentes, homossexuais, profissionais do sexo, entre outros.

Foi também com base na observação do processo estigmatizante que se desenvolveu no campo da saúde a noção de uma dimensão também simbólica da organização de serviços, o que envolveria, não apenas os aspectos objetivos geográficos, econômicos e funcionais, mas as subjetividades elas mesmas e, consequentemente, as dinâmicas relacionais influenciadas pelas crenças e valores dos 
diversos sujeitos e grupos em interação em torno da atenção à saúde (ASSIS e de JESUS, 2012).

As barreiras simbólicas ao acesso da população LGBT aos serviços tem sido frequentemente denunciadas e discutidas, não apenas em relação aos homossexuais masculinos (ALBUQUERQUE e cols, 2013), mas para todos os grupos que compõe a diversidade de orientação. Para as lésbicas e mulheres bixessuais, por exemplo, a discriminação associado ao despreparo dos profissionais de saúde são as principais barreiras para que elas assumam sua orientação sexual durante o atendimento, como aponta, tanto o dossiê realizado pela Rede Feminista de Saúde (2006), quanto estudos acadêmicos como o de VALADÃO E GOMES (2011). No que se refere aos travestis e transexuais, as barreiras simbólicas ao acesso e o comprometimento da qualidade de atenção tem sido relatadas como ainda mais intensas, influenciando desde a dificuldade em se cumprir a determinação de uso do nome social nos prontuários (LIONÇO, 2008) quanto o ainda persistente processo de psiquiatrização da condição de transexualidade para a garantia à cirurgia de redefinção de sexo (ARAN, et cols. 2008).

Além do reconhecimento por programas e políticas públicas de saúde da discriminação enquanto determinantes de saúde e do preconceito institucional enquanto barreira simbólica ao acesso e à boa qualidade de atenção como um todo, mecanismos interministeriais também foram adotados no intuito de fortalecer a promoção do respeito à diversidade. Em 2007 o documento intitulado "Educação como Exercício da Diversidade" do Ministério da Educação já reconhecia que a construção social da noção de epidemia de doenças sexualmente transmitidas, associada às práticas sexuais entre pessoas do mesmo sexo esteve centrada em uma abordagem preconceituosa e excludente (BRASIL, 2007).

Por outro lado, os movimentos sociais, galgaram melhores espaços de participação através dos quais puderam tornar mais visíveis suas principais reivindicações que CARRARA (2010) sintetizou como: livre expressão de orientação sexual, mudança para o nome social em documentos de identidade, acesso à saúde de qualidade e proteção pelo Estado contra a violência motivada pela intolerância à diversidade.

Se por um lado o enfrentamento até agora operado não parece ter sido suficiente para a dissolução no plano das subjetividades de estigmas profundamente encarnados na 
cultura, por outro lado podem funcionar como mediadores do discurso, produzindo, sobretudo, no campo da saúde, o constrangimento de profissionais em assumir de forma explícita seus preconceitos e provocando, em um primeiro momento uma tendência a um discurso performático, alinhado ao politicamente correto que significa a negação do preconceito.

Assim sendo, parece fundamental estudar hermeneuticamente o discurso dos médicos e demais profissionais, buscando revelar ideologias e moralidades subjacentes quanto ao acesso da população LGBT à atenção em saúde. Esse tipo de estudo, entretanto, é praticamente inexistente na literatura brasileira. O contexto de Teresina, caracterizado por uma sociedade sob forte influência religiosa e considerada como uma das mais discriminatórias do país em relação ao grupo LGBT, pode ajudar a compreender melhor como se estruturam esses discursos, contribuindo para o planejamento futuro de estratégias de formação continuada e capacitação.

\section{METODOLOGIA}

Trata-se de um estudo qualitativo de análise de discurso pelo método hermenêutico dialético. Para Minayo (2013), na pesquisa social existe uma identidade entre sujeito e objeto, revelando um substrato comum de identidade com o investigador, tornando sujeitos e pesquisador imbricados e comprometidos numa mesma ciência. A abordagem qualitativa realiza uma aproximação fundamental e de intimidade entre sujeito e objeto, uma vez que ambos são de naturezas próximas.

Foram selecionados por sorteio sete Unidades de Saúde da Família (USF) entre as 22 existentes no município e nelas os profissionais médicos que participaram do estudo. Os critérios de exclusão dos participantes eram: não estar inserido em uma equipe completa de saúde da família, ter menos de três anos de atuação na atenção básica, e não estar cadastrado no Cadastro Nacional de Equipes de Saúde (CNES). Caso as exigências não fossem cumpridas era procedido novo sorteio.

Para coleta de dados foram realizadas entrevistas individuais semiestruturadas que foram gravadas e posteriormente transcritas para que fosse aplicado o exame hermenêutico-dialético, de onde se pretendeu demonstrar as ideologias e moralidades subjacentes às falas. Os participantes foram então codificados, utilizando-se a abreviatura da categoria profisssional "Med" seguido da numeração de 1 a 7. 
O referido projeto de pesquisa foi examinado e aprovado pelo Comitê de Ética em Pesquisa da Faculdade de Saúde da Universidade de Brasília, sob n ${ }^{\circ}$----- (ANEXO 2) e no Comitê de Ética local da Secretaria Municipal de Saúde de Teresina, sob no -----(ANEXO 3). Todos os participantes assinaram o Termo de Consentimento e Livre Esclarecido- TCLE (ANEXO 4).

\section{RESULTADOS E DISCUSSÃO}

"Devem ser inseridos na população normal pra ser encarados com naturalidade"(MED1).

Da análise nas unidades de inferência, emergem quatro categorias principais: 1.percepção confusa entre universalidade e equidade, 2. patologização e percepção de anormalidade na condição, 3. negação de barreira ao acesso e imputabilidade da ausência de procura do serviço aos próprios sujeitos, 4. baixa demanda do grupo LGBT ou invisibilidade da condição .

\section{Percepção Confusa entre Universalidade e Equidade.}

$\mathrm{Na}$ relação entre os médicos e a clientela, percebe-se a partir do material coletado que o discurso da universalização imbrica fortemente o exercício da equidade:

"Não existe nada especial para eles, exatamente porque defendemos a ideia que eles devem estar inseridos dentro da comunidade e sem motivo para que eles sejam segregado de uma forma ou de outra" (MED 1).

"Eles entram na universalidade, não tem serviços e ações especificamente dirigidos só para eles ainda. [...] Um problema a supervalorização desse grupo, enfraquecer os outros, não é?! (MED3).

"Aqui no consultório, qualquer um tem o acesso, independente de ser desse grupo ou não. $\mathrm{O}$ que tem prioridade justamente são aqueles já padronizados oficialmente: idosos, portadores de necessidades especiais, gestantes e crianças de colo"(MED4).

“A gente não tem nada específico para LGBTT. É como eu tô te falando, é um acesso universal, independente de sexo, raça, idade [...] não tem nenhum programa específico. É igual para todo mundo. A facilidade ou dificuldade é a mesma" (MED5). 
A desconsideração do prescrito nos autos da Política Nacional de Atenção Integral a População LGBT, a confusão conceitual e prática entre igualdade e equidade e, ainda as violências simbólicas por parte do profissional, são faces diversas de um mesmo fenômeno. Os fragmentos de diálogos extraídos dos discursos dos profissionais médicos inseridos na rede pública de saúde da capital piauiense sugere certa distância de um modelo de atenção integral e equânime, proposto pelo Sistema Único de Saúde (SUS).

Os esforços das três esferas de governo e da sociedade civil organizada na promoção, atenção e no cuidado em saúde, priorizando a redução das desigualdades por orientação sexual e identidade de gênero, assim como o combate à homofobia, lesbofobia e transfobia, e à discriminação nas instituições e serviços do Sistema Único de Saúde (SUS) serão exíguos caso não haja uma mudança nos paradigmas atuais no campo do discurso e ações médicas.

Faz necessário afirmar que o conceito de igualdade de gênero dado pelos profissionais não respeitam a liberdade que todos os seres humanos, tanto mulheres como homens, possuem para desenvolver as suas capacidades pessoais e fazer escolhas sem as limitações impostas por estereótipos, impostando assim, contrariando o conceito dado por Itaipú (2013) que define igualdade de gênero não pela obrigatoriedade de mulheres e homens serem idênticos, mas que os seus direitos, responsabilidades e oportunidades não dependem do fato de terem nascido com o sexo feminino ou masculino.

A respeito de como são organizadas as ações e serviços dirigidas à população LGBT na unidade de saúde em que os profissionais médicos entrevistados exercem suas funções, há uma unanimidade no discurso, em que alega não haver "nada específico para eles" (MED5). Porém observa-se que a justificativa é baseada basicamente no conceito arraigado de igualdade, focado na universalização de direitos. O ponto de vista da classe médica nem sempre consegue velar-se, de modo que o discurso, embora cuidadoso, evidencia a inobservância médica à Política Nacional de Saúde da População LGBT.

Nesse sentido, faz-se necessária a importância de um olhar que contemple a interação de diversos marcadores de diferença. É imprescindível ainda, que a população LGBT atendida por esses profissionais entrevistados pode estar condicionada a outras formas de opressões por distintos fatores, a exemplo das afirmações de Parker e 
Camargo Jr. (2000) que atrela a opressões advindas da orientação sexual a pobreza, o racismo, a desigualdade de gênero e a homofobia, e quando correlacionadas sistematicamente, proporciona aos sujeitos situação de acentuada vulnerabilidade.

A percepção que a orientação sexual e gênero necessitam para uma atenção integral a saúde não é relacionada a fatores determinantes no processo de saúde/doença ou, ainda, como seus produtos negativos, como preconceito, violência, estigma, discriminação, dentre outros, mas com fatores econômicos, como destaca os discursos dos profissionais médicos entrevistados. A confusão do conceito de universalidade para justificar a ausência de ações específicas para a população LGBT é evidente e clara e contraria o conceito de equidade dado por Itaipú (2013), que garante que homens e mulheres são tratados de forma justa, de acordo com as respectivas necessidades. É importante destacar que dentro desse conceito é abordada a importância do tratamento que deve considerar, valorizar e favorecer, de maneira equivalente, direitos, benefícios, obrigações e oportunidades entre os gêneros.

\section{Patologização e Percepção de Anormalidade na Condição.}

A visão médica da homossexualidade enquanto desvio, continua presente no discurso médico, impactando o cotidiano de busca pelo serviço de saúde:

“Conversava muito com eles (...): não é porque você é desse jeito ai que você vai se jogar não, você pode ter um bom comportamento e ser uma pessoa normal como eu sou, porra! [...] eles tem problemas, mas não vamos esconder, né? vamos botar pra fora, dizer a verdade, que eles têm problema, tem! precisa, precisa ter que ouvir" (MED2).

“Acesso[...] é aquilo que é ofertado para todos, sem distinção, para o normal e para o gay (MED2).

"Eu creio que aqui não tenha ações específicas para esse grupo, ele é atendido como todos. Existe controle da hipertensão, diabetes, tuberculose, hanseníase, outras patologias, mas LGBT não tem!” (MED4).

“ Não existe uma rotina específica para eles aqui na unidade... Às vezes, campanhas, doenças, que eles tem um perfil de risco maior" (MED 6). 
“(...) nenhuma demanda específica com relação a isso. Continua sendo a questão exposição ao agravo sexualmente transmissível continua sendo isso.” (MED 3).

"Preocupados para fazer o exame do HIV. (...) eles são muito preocupados com esse ponto né (...), então é, já sabia de cor, o HIV, Raio X de tórax e o hemograma.” (MED 2).

O presente estudo demonstra que há profissionais que ainda preservam a visão, considerada por Caponi (2012) como arcaica, da ordem médica do século XX que por muito tempo identificou e classificou o segmento LGBT como portadores, em particular, de patologia mental e desvio de conduta sexual. A inobservância das especificidades da população LGBT é reforçada pelos profissionais médicos pelo desconhecimento do conceito e efeito da Discriminação Positiva dada por Reimers (2000), que a evidencia como uma verdadeira redistribuição das oportunidades sociais e como potente arma para responder à aspiração democrática de igualdade de oportunidades.

Os estudos corroboram com os achados de Ayres (1997 e 2005) que afirma que a vulnerabilidade ainda impera nos cenários de saúde. Em períodos em que a população LGBT foi criticada fortemente na história da epidemia da AIDS, onde a vulnerabilidade as quais eram expostos os transformava em serem passíveis de exclusão e maus tratos, como estigmatização e discriminação, atualmente ainda se promove a ideia de que são grupos protagonistas na disseminação da doença e as narrações deste estudo aponta essa repercussão na conduta médica nos dias atuais.

É indiscutível, portanto, que a influência dos padrões sociais de caráter heteronormativos estabelecidos, tem dentro dos espaços de saúde investigados seu espaço de ação. É certo, ainda, de acordo Sousa e colaboradores (2009), que essa influência atua fortemente na conduta profissional, aumentando o risco de alguns não terem os seus direitos respeitados e os afastando dos serviços de saúde, assim como ocorre nos locais em que a demanda LGBT não tem a Unidade Básica de Saúde como referência para suas necessidades integrais, a exemplo do modelo teresinense desse estudo.

A patologização da população LGBT também é evidenciada no discurso dos profissionais pesquisados, onde a relação de ações específicas de atenção integral à saúde da população LGBT a programas de acompanhamento de patologias crônicas 
passíveis de tratamento denotam evidente equiparação entre o individuo LGBT e o paciente acometido por essas doenças.

Outro fator a ser considerado é a forte relação estigmatizante da população LGBT com as Doenças Sexualmente Transmissíveis (DST) que ainda se faz presente nas práticas médicas nos dias atuais, prova disso é a constatação no discurso médico ao afirmar que a procura dos segmentos é restritamente pela preocupação e realização de exames para o diagnóstico de doenças consideradas predominante dos segmentos LGBT, sendo sua conduta replicada por meio de uma rotina padronizada, evidenciada no estudo por meio de solicitação de exames específicos.

Os relatos extraídos no discurso, coletados na entrevista, revelam que a associação entre a população LGBT e DST ainda é reforçada pelos profissionais médicos, onde há uma condenação da orientação sexual ao contato com fatores causadores de doença, principalmente HIV, só reforça o estigma que essa população já enfrenta desde os tempos remotos. Afirmações nesse sentido não promove a saúde dos indivíduos LGBT, mas conseguem influenciá-los de forma negativa para negação ou ,ainda, a privação do usufruto pleno de sua orientação sexual pelo receio psicológico instigado pelo profissional de saúde.

É evidente a forma pela qual o profissional de saúde enxerga e assiste os usuários LGBT, é preciso nesse contexto que o Plano Nacional de Enfrentamento da Epidemia de Aids e das DST entre Gays, HSH (homens que fazem sexo com homens) e Travestis (2007b) seja observado, principalmente na prescrição em que aborda a homofobia e a transfobia iniciada desde o convívio familiar, onde desencadeia barreiras sequenciadas que carecem de superação pelo indivíduo afetado, sendo seus efeitos negativos em vários aspectos, como "autoestima, as dificuldades na sociabilidade, exclusão do convívio familiar e na descontinuidade da educação formal", dentre outras dificuldades que acabam desembocando em diversos outros prejuízos.

Por outro lado, encontramos em um único discurso a percepção de que a população LGBT tem avançado quanto à adoção de medidas de segurança adequadas a prevenção das DSTs:

"Por incrível que pareça, é um grupo que tenha um certo esclarecimento em relação à proteção contra doenças sexualmente transmissíveis" (MED1)

Negação de barreira ao acesso e imputabilidade da ausência de procura do serviço aos próprios sujeitos. 
Na visão médica, o acesso é marcado pela ausência de barreiras, sendo o próprio usuário LGBT responsável por sua ausência na Unidade Básica de Saúde:

"Não existe dificuldade, sempre tem uma maneira que o paciente seja atendido, se não puder vir, nós vamos a sua residência [...] Eu não percebo se há discriminação entre LGBT e outros pacientes da população" (MED2).

"Hoje em dia, a dificuldade que eles tem é a mesma dificuldade que qualquer pessoa comum tenha [...]" (MED6).

"Não, não tem impedimento, é por parte deles mesmo, eles se envergonham, ainda é o tabu, que melhorou bastante, né? melhorou $60 \%$, antigamente andavam escondido, hoje melhorou muito, lá no meu interior fico preocupado, já andam tudo solto já, fazem questão" (MED2).

"Eles mesmo, LGBT, não procuram a unidade como um grupo formado. Se eles não procuram a unidade, se mobilizam, então nós também não temos a oportunidade desse relacionamento [...] Mas nós não temos contato com esse grupo, esse grupo em momento nenhum nos procurou" (MED4).

“A não ser por um preconceito próprio deles, caso tenha, mas não pela equipe, pela UBS, de jeito nenhum! Se tiver, é por eles mesmos, de repente chegar aqui. Mas pela equipe, pela unidade, não!" (MED5).

Não é apenas as práticas discriminatórias que bloqueiam o acesso ao sistema de saúde a população LGBT, mas também, e talvez de forma imperativa, a impropriedade da oferta de atenção e de cuidados. O discurso narrativo comum que alega a ausência da população LGBT nos serviços de saúde, não demonstra boas condição de saúde de lésbicas, gays, bissexuais, travestis ou transexuais, mas uma desatenção às questões relacionadas à orientação sexual ou, ainda, o bloqueio da assistência, já que o acesso para os segmentos LGBT estão condicionados a compreensão das demandas desses grupos, tendo em vista o cumprimento dos princípios da universalidade e integralidade do (SUS).

O Centro Brasileiro de Estudos em Saúde aponta que o setor da saúde tem se mostrado permeável ao debate e à incorporação de desafios e inovações de diversas naturezas, o que ocasiona uma expectativa positiva quanto às mudanças, porém há uma 
ampla constatação de que os direitos humanos dos grupos LGBT são violados ou negligenciados (CEBES, 2013). Corroborando com a última afirmação, constatou-se no estudo que a compreensão de demandas específicas aos segmentos LGBT são ausentes em todas as Unidades Básicas de Saúde (UBS) pesquisadas, marcado pela falta de ações específicas.

Diante dos fatores que imputam o usuário LGBT pela ausência da procura pelos serviços de saúde pelos quais lotam os profissionais entrevistados, a Campanha de Humanização do Ministério da Saúde, evidencia que as violências sofridas pelo cliente dentro do espaço compreendido como estabelecimento de saúde leva a bloqueios e traumas de difícil reparo, não sendo o papel do profissional acelerar este processo ou tentar influenciar as decisões de seus clientes, muito menos "culpabilizá-los por permanecerem, mas sim confiar e investir na sua capacidade para enfrentar os obstáculos" (BRASIL, 2002, p. 58).

Assim, é possível observar, que faz-se necessário nos estabelecimentos de saúde pesquisados, um modelo de saúde cujo serviço seja compatível com as necessidades da comunidade, incluindo a população LGBT. As questões levantadas por Adami (1993) e Unglert (1995) que consideram o formato de serviços oferecidos, os horários previstos e melhoria no atendimento, devem ser reconsideradas para um panorama mais inclusivo e para que as questões como agendas para participação e envolvimento para integração de toda comunidade adscrita, campanhas de integração de populações historicamente exclusas dos serviços por meio dos preconceitos e discriminações e, ainda, o reforço de serviços que considerem e respeitem as peculiaridades, escolhas e modo de vida de cada um.

O presente estudo reforça, na lógica da integralidade à saúde, algumas questões que devem ser cuidadosamente observadas, principalmente as inseridas no campo dos prejuízos e agravos à saúde advindos de processos contínuos e repetitivos de estigmas, discriminação e exclusão social, entendendo esses prejuízos não apenas os físicos, mas como também os psicológicos, cuja amplitude e magnitude são de ampla escala do ponto de vista negativo e irreversíveis, corroborando com os achados de Sousa e cols. (2009) no que se refere a esses tipos de violências no campo da saúde.

As diretrizes e os objetivos da Política Nacional de Atenção Integral da População LGBT estão, portanto, voltados para mudanças na determinação social da saúde, com vistas à redução das desigualdades relacionadas à saúde desses grupos sociais. As diretrizes do SUS reafirmam o compromisso com a universalidade, com a 
integralidade e com a efetiva participação da comunidade. Com a implementação da política, o próprio Ministério da Saúde (2010) reconhece que a identidade sexual e a identidade de gênero são constituintes de um processo complexo de discriminação e de exclusão, do qual derivam os fatores de vulnerabilidade.

\section{Baixa demanda do grupo LGBT ou invisibilidade da condição}

"Nós não temos esse tipo de paciente aqui, eu nunca atendi, nunca se dirigiu pra cá pra nós. [...] Existe ainda um complexo, né? por alguns, outros não, né? fazem questão de ser [...] uns fazem questão de aparecer e outros não, fazem questão de se esconder" (MED2).

"Como a comunidade é reduzida, pelo menos aquelas que sejam sabidas, que sejam bem expostos, que tenha algum grau de revelação, a demanda é pequena, é curta" (MED3).

"Na verdade, quando o paciente procura a nossa equipe [...], a gente não procura identificar sua opção sexual [...]independente de sua opção, nós atendemos a todos" (MED4).

"Também, é aquela coisa, que a gente saiba que é LGBTT, não tem! Por exemplo, eu sou LGBTT e quero uma consulta, não, não tem! É uma pessoa qualquer que vem para uma consulta aqui no posto e vai ser atendido de qualquer forma" (MED5).

"É pequena, a demanda, e existe ainda muito preconceito, principalmente dos próprios familiares" (MED6).

"Não, muito pouco. Se eu tiver três, eu tenho muito. Muito pouca a procura. E é porque a gente atende bem, recebe bem. Se eu tiver três, tenho muito, que eu faço acompanhamento" (MED7).

Frente às violências simbólicas, como também as agressões firmadas pelo desrespeito, a revelação ao outro da orientação sexual torna-se uma tarefa árdua e difícil, evidenciada por Foucault como silenciamento da sexualidade. Nesse contexto, identifica-se neste estudo essa complexidade pelos quais o indivíduo expressa sua sexualidade, corroborando com os estudos de Abdo (2004) que tal fator pode estar relacionado por relacionamentos, circunstâncias de vida ou pela cultura, o que pressupõe ser algo construído gradualmente e por caracterizar a performance e identidade de gênero.

A Política Nacional de Atenção Integral a População LGBT (PNAILGBT), também reconhece a complexidade envolvida no processo de desnaturalização dos preceitos heteronormativos que levam a ações discriminatórias, por prevê em seu escopo um longo e difícil caminho a ser percorrido, alertando que a maior dificuldade 
"será a superação do preconceito e da discriminação que requer, de cada um e do coletivo, mudanças de valores baseadas no respeito às diferenças" (BRASIL, 2013, p. 16).

As condições expostas que relatam a ausência da população LGBT nas unidades de saúde e, ainda, um atendimento ao individuo cuja orientação sexual, anseios e problemas são velados ao profissional e restrito ao paciente. O Programa Brasil Sem Homofobia, prescreve desde 2002, que o cuidado integral por parte do sistema de saúde só é possibilitado mediante uma relação de vínculo firmado quando o respeito de ambas as partes são evidenciados de forma recíproca. Portanto, o papel do profissional de saúde é facilitar o diálogo, "agindo com tato e diplomacia na busca da orientação ou encaminhamento mais adequado a cada caso" (BRASIL, 2002, p. 74).

Os Profissionais médicos denunciam a falta de procura pela população LGBT ao serviço de saúde, embora não ofereça nenhum cuidado específico a essa população, ele alega nunca ter tido contato com nenhum segmento. $\mathrm{O}$ acesso além de portões abertos é fundamental para a efetivação da Política Nacional de Atenção Integral a População LGBT, para que assim as barreiras simbólicas existentes entre o serviço de saúde e o usuário possam ser transformadas em um processo de vinculação mútua pelo estabelecimento de confiança, levando a construção de mais saúde a uma população tão negligenciada ao longo do tempo e que ainda vive em condições de vulnerabilidade.

Com a universalidade do direito à saúde, faz-se necessário que se proponham estratégias de acolhimento e de atenção específicas, de acordo com as singularidades dos sujeitos que buscam assistência. Assim, é preciso que o estado brasileiro defina de forma mais objetiva o reconhecimento das perspectivas da equidade, como reforça Lionço (2009) que considera primordial o delineamento da equidade nos sistemas, já que além da universalidade dos direitos humanos e sociais, garante o reconhecimento e a consideração das diferenças entre os grupos sociais que, muitas vezes, como a população LGBT, encontra-se em situação de desigualdade.

Assim, para que a mudança desejada no cenário do acesso à saúde pela população LGBT ocorra, é fundamental que os profissionais e os gestores da saúde invistam na ideia de que os fatores relacionados à orientação sexual e a identidade de gênero são importantes determinantes dos processos de cura e adoecimento, assim como afirma Buss e Pellegrini Filho (2007), que relaciona ainda a outros condicionantes que 
interferem diretamente no perfil epidemiológico e, consequentemente, do perfil patológico e da mortalidade, como classe social, escolaridade, entre outros.

\section{CONSIDERAÇÕES FINAIS}

Implementar a Política Nacional de Atenção Integral para a população LGBT continua sendo um desafio, já que torna-se imperiosa a ampliação da percepção do que se compreende por direitos sociais, reprodutivos e o reconhecimento das diversas possibilidades de constituição humanas e, ainda, impreterivelmente, o exercício da sexualidade.

Insta salientar que embora diversas ações para promoção ao respeito à diversidade já tenha progredido em alternos setores, inclusive no campo da saúde, o presente estudo demonstra que faz-se necessário a mudança de concepções e práticas por parte dos profissionais de saúde para que, além de conhecerem e apropriarem das causas prescritas na política, possam construir um novo cenário na Atenção Básica de Saúde.

Grandiosas foram às vitórias da população LGBT em positivar no ordenamento jurídico, direitos fundamentais para o exercício da cidadania e, ainda, para garantia de sua saúde, como um atendimento humanizado e livre de preconceito e discriminação por orientação sexual e identidade de gênero, inclusive assegurando o uso do nome social para travestis e transexuais como estratégia de promoção de acesso ao sistema, por meio da Carta dos Direitos dos Usuários da Saúde, porém, ações, não menos complexas, precisam ser adotadas para que esses direitos possam ser incorporados e reconhecidos como tal pelos trabalhadores da saúde, o que requer mudanças de valores baseado nos respeito às diferenças, não sendo diferente a realidade teresinense abordada nesse estudo.

Obviamente, os achados do presente estudo não podem ser generalizados para o Brasil como um todo e os resultados do estudo em outras regiões permitirá uma compreensão mais ampla do fenômeno, entretanto, não se espera resultados muito diferentes em contextos semelhantes ao de Teresina, marcado por forte religiosidade tradicional e homofobia. 


\section{REFERÊNCIAS}

ABDO C. H. N. Descobrimento sexual do Brasil: para curiosos e estudiosos. São Paulo: Summus, 2004.

ADAMI, N. P., 1993. Acesso aos serviços de dermatologia de um centro de saúde escola sob o modo de ver dos hansenianos. Revista Paulista de Enfermagem, 12:82-86.

ALBUQUERQUE, Grayce Alencar et al. Homossexualidade e o direito à saúde: um desafio para as políticas públicas de saúde no Brasil. Saúde debate [online]. 2013, vol.37, n.98, pp. 516-524. ISSN 0103-1104.

ARÁN, M.; ZAIDHAFT, S.; MURTA, D. Transexualidade: corpo, subjetividade e saúde coletiva. Psicologia e Sociedade, Porto Alegre, v. 20, nº 1, 2008.

ASSIS, Marluce Maria Araújo and JESUS, Washington Luiz Abreu de. Acesso aos serviços de saúde: abordagens, conceitos, políticas e modelo de análise. Ciênc. saúde coletiva [online]. 2012, vol.17, n.11, pp. 2865-2875. ISSN 14138123. http://dx.doi.org/10.1590/S1413-81232012001100002.

AYRES, J. R. C. M. Epidemiologia e emancipação. 2.ed. São Paulo: Hucitec, 2005.

AYRES, José Ricardo Carvalho Mesquita; JÚNIOR, Ivan França; CALAZANS, Gabriela Junqueira. Saúde Reprodutiva em Tempos de AIDS (II Seminário). AIDS, vulnerabilidade e prevenção. Rio de Janeiro: ABIA, 1997. p. 32, 34.

BARBOSA, R. M.; FACCHINI, R. Acesso a cuidados relativos à saúde sexual entre mulheres que fazem sexo com mulheres em São Paulo, Brasil. Cadernos de Saúde Pública, Rio de Janeiro, v. 25, supl. 2, p. s291-s300, dez. 2009. doi: 10.1590/S0102311X2009001400011.

BRASIL. Ministério da Saúde. Programa Humanização do Parto: Humanização do PréNatal e Nascimento. Brasília, Ministério da Saúde, 2002.

Constituição da República Federativa do Brasil: Texto constitucional promulgado em 5 de outubro de 1988. Brasília: Senado Federal, Subsecretaria de Edições Técnicas, 2004.

Ministério da Educação. Educação como exercício da diversidade. Ministério da Educação, 2007. 
Ministério da Saúde. Secretaria de Vigilância em Saúde. Boletim Epidemiológico HIV/Aids. a. IV, n. 01, Brasília/DF, 2007 b.

Ministério da Saúde. Conselho Nacional de Combate à Discriminação. Brasil sem homofobia: programa de combate à violência e à discriminação contra LGBT e promoção da cidadania homossexual. Brasília: Ministério da Saúde, 2004.

Ministério da Saúde. Política nacional de saúde integral de lésbicas, gays, bissexuais, travestis e transexuais. Brasília: Ministério da Saúde, 2010.

Ministério da Saúde. Política nacional de saúde integral de lésbicas, gays, bissexuais, travestis e transexuais. Brasília. $1^{a}$ Edição. $1^{a}$ Reimpressão. Ministério da Saúde, 2013.

Ministério da Saúde. Secretaria de Atenção à Saúde. Departamento de Atenção Básica. Política Nacional de Atenção Básica. Ministério da Saúde, 2011.

BUSS, P. M.; PELLEGRINI FILHO, A. A saúde e seus determinantes sociais. Physis, Rio de Janeiro, v. 17, n. 1, p. 77-93, abr. 2007.

CAMPOS, G. W. S. Considerações sobre a arte e a ciência da mudança: revolução das coisas e reforma das pessoas. O caso da saúde. In: CECÍlLIO, L. C. O. (Org.). Inventando a mudança na saúde. 2. ed. São Paulo: Hucitec, 1997, p. 29-87.

CAPONI, S. Loucos e Degenerados: uma genealogia da psiquiatria ampliada. Rio de Janeiro: Editora da Fiocruz, 2012.

CAPONI, S. Loucos e Degenerados: uma genealogia da psiquiatria ampliada. Rio de Janeiro: Editora da Fiocruz, 2012.

CARRARA, S. Moraes C. Um vírus só não faz doença. Cad Inst. Med. Social. 1987; (1):96-123.

CARRARA, S. Políticas e direitos sexuais no Brasil contemporâneo. BAGOAS, n. 05, p. 131-147, 2010. 
CARVALHO, L. S.; PHILIPPI, M. M. Percepção de lésbicas, gays e bissexuais em relação aos serviços de saúde. Universitas: Ciências da Saúde, Brasília, v. 11, n. 2, p. 83-92, jul./dez. 2013. doi: 10.5102/ucs.v11i2.1837.

CEBES. Centro Brasileiro de Estudos em Saúde. Editorial da Revista Saúde em Debate - Edição 98. Rio de Janeiro. V.37, n. 98. Jul/set de 2013.

DONABEDIAN, A. An introduction to quality assurance in health care. Oxford University Press. New York, 2003.

ITAIPU, Binacional. Equidade de Gênero: Como implementar na gestão das empresas?. Cartilha, 36 pag. 1 ed. Brasília, 2013. Acesso em 04 de dez de 2015. Disponível em: http://premiowepsbrasil.org/wpcontent/uploads/2013/11/Cartilha_EquidadeGenero_Itai pu.pdf

LIONÇO T. Atencao integral à saúde e diversidade no processo transexualizador no SUS: avancos, impasses e desafios. Physis Revista de Saúde Coletiva 2009: 43-63.

LIONÇO, T. Que direito à saúde para a população GLBT? Considerando direitos humanos, sexuais e reprodutivos em busca da integralidade e da equidade. Saúde e Sociedade, São Paulo, v. 17, n. 2, p.11-21, apr.jun. 2008. doi: 10.1590/S010412902008000200003.

MELLO L. et al. Por onde andam as Políticas Públicas para a População LGBT no Brasil. Revista Sociedade e Estado, v. 27, n. 2, maio 2012.

MELO L. et al. Por onde andam as Políticas Públicas para a População LGBT no Brasil. Revista Sociedade e Estado, v. 27, n. 2, maio 2012.

MILLMAN, M. Acess to health care in America. Washington, DC: National Academy Press, 1993.

MINAYO, M.C.S. O desafio do conhecimento: pesquisa qualitativa em saúde. 13. ed. São Paulo: Hucitec, 2013.

PAIVA, V. Sexualidade na saúde pública. Psicologia Ciência e Profissão, São Paulo, v. 3, n. 4, 2006. 
PARKER, Richard \& CAMARGO JR., Kenneth Rochel de. 2000. "Pobreza e HIV/AIDS: aspectos antropológicos e sociológicos". Cad. Saúde Pública, Rio de Janeiro, 16 (Sup. 1), p. 89-102.

Rede Feminista de Saúde. (2006). Dossiê Saúde das Mulheres Lésbicas: promoção da equidade e da integralidade. Belo Horizonte: Autor.

REIMERS ARIAS, F. Educación, desigualdad y opciones de política en América Latina en el siglo XXI. Revista Iberoamericana de educación, Madrid, n. 23, p. 21-50, Mayo/Ago. 2000.

Sistema de Informação da Atenção Básica (SIAB). 2009. Cadernos de Informações de Saúde - Piauí. Planilha referente ao Caderno do município de Teresina. 2009. [acessado 2015 jul 28]. Disponível em:http://tabnet.datasus.gov.br/tabdata/cadernos/pi.htm.

ROSA, A. R.; BRITO, M. J. Ensaio sobre violência simbólica nas organizações. Organizações \& Sociedade, v. 16, n. 51, art. 2, p. 629-646, 2009.

SOUSA, M. F. Saúde da Família e os Conceitos Necessários. In: Programa Saúde da Família no Brasil. Análise da desigualdade no acesso à atenção básica. Brasília, Editora do Departamento de Ciências da Informação e Documentação da Universidade de Brasília, v.1, 2007. 250p.

SOUSA, P. J., Abrão, F. M. S., Costa, A. M. C., \& Ferreira, L. O. C. F. (2009) Humanização no acolhimento de gays, lésbicas, bissexuais, travestis e transexuais na atenção básica: reflexões bioéticas para enfermagem. In Anais do Segundo Seminário Nacional de diretrizes para enfermagem na atenção básica em saúde, $2^{\circ}$ SENABES. Recife, PE: Associação Brasileira de Enfermagem. Recuperado em 15 março, 2010, da ABEN:http://www.abeneventos.com.br/SENABS/cd_anais/pdf/id141r0.pdf

SOUSA, P. J.; ABRÃO, F. M. S.; COSTA, A. M. C. Humanização no acolhimento de gays, lésbicas, bissexuais, travestis e transexuais na atenção básica: reflexões bioéticas para enfermagem. In: Seminário Nacional De Diretrizes Para Enfermagem Na Atenção Básica Em Saúde, 2. 2009, Recife, PE. Anais. Recife, PE: Associação Brasileira de Enfermagem, 2009. Disponível em: http://www.abeneventos.com.br/SENABS/ cd_anais/pdf/ id141r0.pdf. Acesso em: 15 mar. 2010. 
STARFIELD, B: Accesibilidad y primer contacto: El "filtro". Atención Primaria: equilibrio entre necesidades de salud, servicios y tecnología. MASSON S.A. Barcelona. 2004.

UNGLERT, C. V. S., 1995. Territorialização em sistemas de saúde. In: Distrito Sanitário (E. V. Mendes, org.), pp. 221-235, São Paulo: Editora Hucitec/Rio de Janeiro: ABRASCO.

VALADÃO, R. C.; GOMES, R. A homossexualidade feminina no campo da saúde: da invisibilidade à violência. PHYSIS - Revista de Saúde Coletiva, Rio de Janeiro, v. 21, n. 4, p. 1451-1467, 2011. 


\section{CONSIDERAÇÕES FINAIS DA DISSERTAÇÃO}

Assim, o presente estudo considera fundamental a discussão através da fusão elementos chave, como a heteronormatividade, estigma e homofobia, por entender que os processos que definem sua associação produzem negativas consequências para a população LGBT no campo da saúde.

Frente às discussões levantadas, nota-se que a necessidade de aprofundar as análises na perspectiva de avaliar as ações e os serviços voltados à população LGBT na perspectiva de outros profissionais ainda se faz presente, como também a associação desses resultados com as demais estações de pesquisa, para que assim inferências mais amplas e completas sejam possibilitadas a nível nacional, acreditando que os outros resultados irão corroborar com os levantados por esta investigação.

É evidente que as relações entre os profissionais e usuários pertencentes à população LGBT das unidades pesquisadas são fragilizadas, seja pela falta de preparo do profissional ou mesmo pela auto-estigmatização dos usuários, que, conhecedores do preconceito, se distanciam e desfaz laços importantes com o sistema de saúde.

Por fim, ressalta-se a necessidade de mais integração entre os diversos segmentos e serviços de saúde, a fim de que planos e programas se tornem instrumentos efetivos de promoção de cidadania e direitos humanos, do contrário, corre-se o risco do rompimento com essa população, impossibilitando as propostas executoras. Simplificar os serviços de modo a deixá-los mais acessíveis a qualquer indivíduo torna a Política Nacional de Atenção Integral a População LGBT ou as demais exequíveis e com possibilidade de grande alcance. 


\section{REFERÊNCIAS}

ABDO C. H. N. Descobrimento sexual do Brasil: para curiosos e estudiosos. São Paulo: Summus, 2004;

ADAMI, N. P.. Acesso aos serviços de dermatologia de um centro de saúde escola sob o modo de ver dos hansenianos. Revista Paulista de Enfermagem, 1993. 12:82-86;

AINLAY, S.C.; BECKER, G.; COLMAN, L. M. A. Stigma reconsidered. In.: The Dilemma of Difference. New York: Plenum, 1986. p.1-3;

AYRES, J. R. C. M. Epidemiologia e emancipação. 2.ed. São Paulo: Hucitec, 2005;

AYRES, José Ricardo Carvalho Mesquita; JÚNIOR, Ivan França; CALAZANS, Gabriela Junqueira. Saúde Reprodutiva em Tempos de AIDS (II Seminário). AIDS, vulnerabilidade e prevenção. Rio de Janeiro: ABIA, 1997. p. 32, 34;

BARBOSA, R. M., FACCHINI, R. Acesso a cuidados relativos à saúde sexual entre mulheres que fazem sexo com mulheres em São Paulo, Brasil. Cadernos de Saúde Pública, Rio de Janeiro, v. 25, suppl 2, p. 291-300, 2009;

BARBOSA, R. M.; FACCHINI, R. Acesso a cuidados relativos à saúde sexual entre mulheres que fazem sexo com mulheres em São Paulo, Brasil. Cadernos de Saúde Pública, Rio de Janeiro, v. 25, supl. 2, p. s291-s300, dez. 2009. doi: 10.1590/S0102311X2009001400011.

BORRILLO, D. Homofobia. Barcelona: Ediciones Bellaterra, 2001;

BORRILLO, Daniel. Homofobia: história crítica de um preconceito. Belo Horizonte: Autêntica Editora, 2009. 141 p;

BRASIL. Conselho Nacional de Combate à Discriminação. Brasil Sem Homofobia: programa de combate à violência e à discriminação contra GLTB e promoção da cidadania homossexual. Brasília: Ministério da Saúde, 2004;

Constituição da República Federativa do Brasil: Texto constitucional promulgado em 5 de outubro de 1988. Brasília: Senado Federal, Subsecretaria de Edições Técnicas, 2004;

. Ministério da Saúde. Política nacional de saúde integral de lésbicas, gays, bissexuais, travestis e transexuais. Brasília: Ministério da Saúde, 2010;

Ministério da Saúde. Portaria GM n. 1.707, de 18 de agosto de 2008. Institui, no âmbito do Sistema Único de Saúde (SUS), o Processo Transexualizador, a ser implantado nas unidades federadas, respeitadas as competências das três esferas de gestão. Brasília: Ministério da Saúde, 2008; 
. Plano Nacional de Promoção da Cidadania e Direitos Humanos LGBT. Brasília: Secretaria Especial de Direitos Humanos da Presidência da República, 2009; . Política Nacional de Atenção Básica. Ministério da Saúde, 2011; . Política Nacional de Saúde Integral de LGBT. Brasília: Ministério da Saúde, 2010 Portaria GM n. 426, de 22 de março de 2005. Institui, no âmbito do SUS, a Política Nacional de Atenção Integral em Reprodução Humana Assistida e dá outras providências. Brasília: Ministério da Saúde, 2005;

Portaria GM n. 675, de 30 de março de 2006. Aprova Carta dos Direitos dos Usuários da Saúde, que consolida os direitos e deveres do exercício da cidadania na saúde em todo o país. Brasília, DF: Ministério da Saúde, 2006;

BUTLER, J. (2003). Problemas de gênero: feminismo e subversão da identidade. Rio de Janeiro: Civilização Brasileira;

BUTLER , J. Cuerpos que importam: sobre los limites materiales y discursivos del "sexo". Buenos Aires: Paidós, 2005, p. 17-49 e 179-203;

BUTLER Judith. "Fundamentos contingentes: o feminismo e a questão do pós-modernismo". Cadernos Pagu, n. 11, p. 11-42, 1998. Tradução de Pedro Maia Soares para versão do artigo "Contingent Foundations: Feminism and the Question of Postmodernism", no Greater Philadelphia Philosophy Consortium, em setembro de 1990;

CAMPOS, G. W. S. Considerações sobre a arte e a ciência da mudança: revolução das coisas e reforma das pessoas. O caso da saúde. In: CECÍlLIO, L. C. O. (Org.). Inventando a mudança na saúde. 2. ed. São Paulo: Hucitec, 1997, p. 29-87;

CARdoso, M. R.; FERRO, L. F. Saúde e População LGBT: Demandas e Especificidades em Questão. Psicologia: ciência e profissão, v. 32, n.3, p.552-563, 2012;

CARRARA, S. Moraes C. Um vírus só não faz doença. Cad Inst. Med. Social. 1987; (1):96-123;

CHOERI, R. C. S., O conceito de identidade e a redesignação sexual, 2004, p. 53;

CORTESÃO, I., SILVA, M. A., TORRES, M. A. (1989). Educação para uma Sexualidade Humanizada. Porto: Afrontamento;

DANTAS, B. S. A. (2010). Sexualidade, cristianismo e poder. Estudos e Pesquisa em Psicologia, 10(3), 700-728.; 
DONABEDIAN, A. An introduction to quality assurance in health care. Oxford University Press. New York, 2003;

DUARTE, E. E. C. O processo histórico dos direitos humanos. Ponta Grossa: UEPG/NUTEAD, 2014, 97 ;

DUARTE. J. O. M. Diversidade Sexual, Políticas Públicas e Direitos Humanos: Saúde e Cidadania LGBT em cena. Revista Temporais. Ano 14, n. 27, p. 77-98, jan./jun. 2014. Brasília-DF;

FONE, Byrne. Homophobia. Nova Iorque: Picador, 2000. 421 p;

FOSTER, David W. Consideraciones sobre el estudio de la heteronormatividade en la literatura latinoamericana. Letras: literatura e autoritarismo, Santa Maria, n. 22, jan./jun. 2001.;

FOUCAULT, M. La volonté de savoir. Paris: Gallimard, 1976;

2007. Security, territory, population: lectures at the Collège de France, 1977-1978. New York: Palgrave Macmillan;

Os Anormais: curso no Collège de France: 1974 - 1975. São Paulo: Martins Fontes, 2001;

FREUD, S. (s.d./1924). Três Ensaios Sobre a Teoria da Sexualidade. (tradução Ramiro da Fonseca). Lisboa: Edição "Livros do Brasil";

GGB. Assassinato de Homossexuais (LGBT) no Brasil: Relatório 2013. Salvador-BA, 2013;

GGB. Assassinato de Homossexuais (LGBT) no Brasil: Relatório 2014. Salvador-BA, 2014;

GGB. Assassinato de Homossexuais (LGBT) no Brasil: Relatório 2015. Salvador-BA, 2015;

GOFFMAN, Erwin. Estigma. Rio de Janeiro, Zahar, 1975 [1963];

HEREK, G.M. (2004). Beyond "homophobia": Thinking about sexual prejudice and stigma in the twenty-first century. Journal of NSRC, 1(2), 6-18;

LIONÇO T. Atencao integral à saúde e diversidade no processo transexualizador no SUS: avancos, impasses e desafios. Physis Revista de Saúde Coletiva 2009: 43-63;

LIONÇO, T. \& Diniz, D. (2009). Homofobia e educação: um desafio ao silêncio. Brasília: Letras Livres; EdUnB; 
LIONÇO, T. Que Direito à Saúde para a População GLBT? Considerando Direitos Humanos, Sexuais e Reprodutivos em Busca da Integralidade e da Equidade. Saúde e Sociedade, São Paulo, v.17, n.2, p.11-21, 2008;

MELLO L. et al. Por onde andam as Políticas Públicas para a População LGBT no Brasil. Revista Sociedade e Estado, v. 27, n. 2, maio 2012;

MELO L. et al. Por onde andam as Políticas Públicas para a População LGBT no Brasil. Revista Sociedade e Estado, v. 27, n. 2, maio 2009;

MELO, L. et al. Políticas de saúde para lésbicas, gays, bissexuais, travestis e transexuais no Brasil: em busca de universalidade, integralidade e equidade. Sexualidade, Salud e Sociedad, n.9, p. 7-28, 2011;

MEYER, D. E. Gênero e educação: teoria e política. In: LOURO, G. L.; NECKEL, J. F.; GOELLNER, S. Corpo, gênero e sexualidade: um debate contemporâneo na educação. Petrópolis: Vozes, 2003;

MINAYO, M.C.S. O desafio do conhecimento: pesquisa qualitativa em saúde. 13. ed. São Paulo: Hucitec, 2013;

MIRANDA, Francielle Felipe Faria. Heteronormatividade: uma leitura sobre construção e implicações na publicidade. Fragmentos de Cultura (Online), v. 20, p. 81-94, 2010;

MOTT, Luiz . Causa mortis: homofobia. Salvador: Editora do Grupo Gay da Bahia, 2001;

MOTT, Luiz. A construção da cidadania homossexual no Brasil. In: Rev. Democracia Viva, jan/fev, $\mathrm{n}^{\mathrm{o}}$ 25, p. 98-102, 2005. Disponível em: http://www.observatoriodeseguranca.org/files/ibasenet_0.pdf;

MOTT, Luiz; ALMEIDA, Claudio; CERQUEIRA, Marcelo. Epidemia do ódio 260 homossexuais foram assassinados no Brasil em 2010. Matéria online. 2011. Disponível em: http://coral.ufsm.br/congressodireito/anais/2015/2-18.pdf. Acesso em 27 de out de 2015

PAIVA, V. Sexualidade na saúde pública. Psicologia Ciência e Profissão, São Paulo, v. 3, n. 4, 2006;

PEREIRA, H; LEAL, I. P. A identidade (homo)sexual e os seus determinantes: implicações para a saúde. Análise Psicológica, v. 3, n. 23, p. 315-322, 2005;

PEREIRA, M.M., FREITAS, F. (2001). Educação Sexual - Contextos de Sexualidade e adolescência. Porto: Asa;

RAMOS, S. CARRARA, S. A Constituição da Problemática da Violência contra Homossexuais: a Articulação entre Ativismo e Academia na Elaboração de Políticas 
Públicas. PHYSYS: Revista de Saúde Coletiva, Rio de Janeiro, v. 16, n. 2, p. 185-205, 2006;

SOUSA, M. F. Saúde da Família e os Conceitos Necessários. In: Programa Saúde da Família no Brasil. Análise da desigualdade no acesso à atenção básica. Brasília, Editora do Departamento de Ciências da Informação e Documentação da Universidade de Brasília, v.1, 2007. 250p;

SOUSA, P. J.; ABRÃO, F. M. S.; COSTA, A. M. C. Humanização no acolhimento de gays, lésbicas, bissexuais, travestis e transexuais na atenção básica: reflexões bioéticas para enfermagem. In: SEMINÁRIO NACIONAL DE DIRETRIZES PARA ENFERMAGEM NA ATENÇÃO BÁSICA EM SAÚDE, 2., 2009, Recife, PE. Anais... Recife, PE: Associação Brasileira de Enfermagem, 2009. Disponível em: http://www.abeneventos.com.br/SENABS/ cd_anais/pdf/ id141r0.pdf. Acesso em: 15 mar. 2010;

STARFIELD, B: Accesibilidad y primer contacto: El "filtro". Atención Primaria: equilibrio entre necesidades de salud, servicios y tecnología. MASSON S.A. Barcelona. 2004;

TESHAINER, Marcus Cesar Ricci. Psicanálise e biopolítica: contribuição para a ética e a política em Michael Foucault. Porto Alegre, RS: Zouk, 2008;

UNGLERT, C. V. S., 1995. Territorialização em sistemas de saúde. In: Distrito Sanitário (E. V. Mendes, org.), pp. 221-235, São Paulo: Editora Hucitec/Rio de Janeiro: ABRASCO;

VAINFAS, R. Casamento, amor e desejo no Ocidente Cristão. São Paulo: Editora Ática, 1986 ;

VALADÃO, R. C.; GOMES, R. A homossexualidade feminina no campo da saúde: da invisibilidade à violência. PHYSIS - Revista de Saúde Coletiva, Rio de Janeiro, v. 21, n. 4, p. 1451-1467, 2011;

WEEKS, Jeffrey. Sexuality (Key Ideas). 2a. Edição. Routledge, 2003. 


\section{ANEXOS:}

\section{CONASEMS}

Conselho Nacional de Secretarias Municipais de Saúde

Brasília, 27 de março de 2014.

IImo.(a). Sr.(a).

Secretário(a) Municipal de Saúde

Assunto: Apoio à pesquisa nacional.

Prezado(a) Senhor(a),

Durante o ano de 2014, o Núcleo de Estudos em Saúde Pública, da Universidade de Brasília - UnB, em parceria nacional com Instituições de Ensino e Pesquisa (Centro de Pesquisas Aggeu Magalhães - CpqAM, Universidades Federais da Paraíba, Piauí, Uberlândia, Universidades Estaduais de Maringá e do Rio de Janeiro e Universidade de São Paulo), com o apoio do Ministério da Saúde, realizará a pesquisa Análise do acesso e da qualidade da Atenção Integral à Saúde da população LGBT no Sistema Único de Saúde.

No período, receberão as visitas das equipes de pesquisa os municípios no Norte / Pará: Belém e Santarém; Amapá: Macapá; Acre: Rio Branco. No Nordeste / Bahia: Salvador, Feira de Santana e Vitória da Conquista; Pernambuco: Recife; Paraíba: João Pessoa; Ceará: Fortaleza e Juazeiro do Norte; Piauí: Teresina e Picos. No Centro-Oeste / Mato Grosso do Sul: Campo Grande. Distrito Federal: Brasília; Ceilândia; Taguatinga e Sobradinho. Goiás: Goiânia. No Sudeste / Rio de Janeiro: Rio de Janeiro; São Paulo: São Paulo e São José do Rio Preto; Minas Gerais: Belo Horizonte e Uberlândia; Espírito Santo: Vitória. No Sul / Paraná: Curitiba e Maringá; Rio Grande do Sul: Porto Alegre.

Pelo exposto e por considerar de suma importância tão relevante investigação, como apoio à gestão do Sistema Único de Saúde (SUS) junto às Secretarias Municipais de Saúde, informamos o aceite do Conselho Nacional de Secretarias Municipais de Saúde (CONASEMS) ao pedido de apoio à pesquisa citada.

Pelo exposto, reiteramos nosso pedido de parceria às SMS e elevamos nossos votos de estima e consideração.

Atenciosamente,

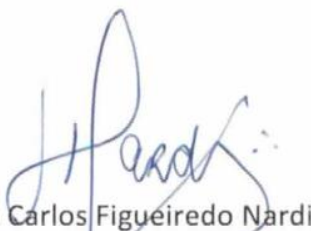

Antônio Carlos Figueiredo Nard

PRESIDENTE DO CONASEMS

Esplanada dos Ministérios, Bloco G. Edificio Anexo, Sala 144B

CEP: 70058-900 | Brasilia/DF

Tel: (061) 3223-0155 | Fax: (61) 3223-0155

E-mail: conasems@conasems.org.br

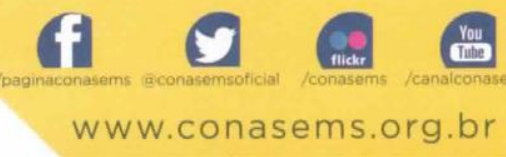




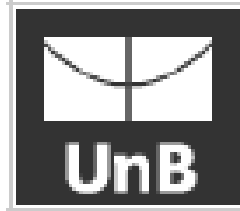

\section{FACULDADE DE CIÊNCIAS DA SAÚDE DA UNIVERSIDADE DE BRASÍLIA - CEP/FS-UNB}

\section{PARECER CONSUBSTANCIADO DO CEP}

\section{DADOS DO PROJETO DE PESQUISA}

Título da Pesquisa: Análise do acesso e da qualidade da Atençäo Integral à Saúde da populaçäo LGBT no Sistema Único de Saúde.

Pesquisador: Maria Fátima de Sousa

Area Temática:

Versäo: 3

CAAE: 25858613.8 .0000 .0030

Instituiçäo Proponente:Faculdade de Cièncias da Saúde da Universidade de Brasília

Patrocinador Principal: Secretaria de Gestão Participativa

\section{DADOS DO PARECER}

Número do Parecer: 652.643

Data da Relatoria: 07/05/2014

\section{Apresentação do Projeto:}

O presente projeto de pesquisa pretende analisar o acesso e a qualidade da atenção integral à saúde da população de Lésbicas, Gays, Bissexuais, Transexuais e Travestis (LGBT), no Sistema Único de Saúde (SUS). Para tanto, vai mapear as dimensöes do acesso desta população aos serviços de atenção básica, média e alta complexidade, na perspectiva dos usuários, profissionais e gestores. $O$ projeto vai comparar os elementos das dimensões do acesso e da qualidade identificados com as açôes preconizadas pela Política Nacional de Saúde Integral a LGBT, bem como identificar estratégias e redes para a atençăo à saúde, acessadas pela população LGBT. Trata-se de pesquisa qualitativa, que utilizará a triangulaçäo de técnicas de coleta de dados, uma vez que há diferentes participantes envolvidos no estudo, o que permitirá ampliar as informações referentes ao objeto da pesquisa. Participarão da pesquisa a população LGBT, gestores locais/municipais, gerentes das Unidades Básicas de Saúde, com foco nas Unidades Básicas que operam na lógica organizativa da Estratégia Saúde da Família. O estudo será de abrangència nacional e contemplará as cinco regiöes: no Norte, Belém, Santarém, Macapá e Rio Branco. No Nordeste, Salvador, Feira de Santana,

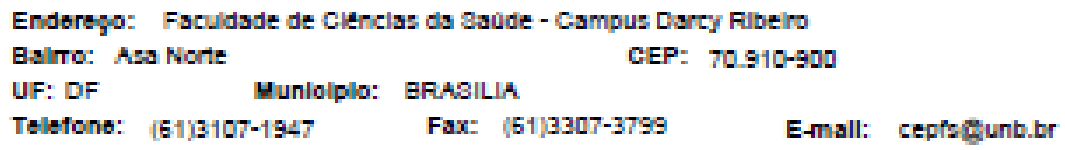




FACULDADE DE CIÊNCIAS DA
UnB
SAÚDE DA UNIVERSIDADE DE
BRASILIA - CEPIFS-UNB

Cortinuaçbo do Parecec: 652.643

Vitória da Conquista, Recife; Joäo Pessoa, Fortaleza, Juazeiro do Norte, Teresina, Picos. No Centro-Oeste, Campo Grande, Brasilia, Cellândia, Taguatinga, Sobradinho, Goiânia. No Sudeste, Rio de Janeiro, Săo Paulo, Săo José do Rio Preto, Belo Horizonte, Uberlândia, Vitória. No Sul, Curitiba; Porto Alegre e Pelotas. A coleta dos dados será realizada por meio de um questionário eletrónico e entrevistas individuais semiestruturadas, a serem aplicadas com os gestores dos municipios, gerentes das Unidades Básicas de Saúde, profissionais das equipes de Saúde da Família, e ainda Grupos Focais com a População LGBT. A análise dos dados será mediada pelo uso dos softwares NVivo9 e Qualiqualisoftware do Discurso do Sujeito Coletivo. A estimativa é de 100 participantes, incluindo a populaçăo LGBT, profissionais de saúde e gestores. O questionário eletrônico, a ser desenwolvido pelo Centro de Tecnologias Educacionais Interativas em Saúde (CENTEIAS), incluirá questöes dirigidas aos gestores do SUS. As entrevistas individuais semiestruturadas, serão aplicadas aos gestores dos municípios, gerentes das Unidades Básicas de Saúde e profissionais das equipes de Saúde da Família. Os Grupos Focais (GF) serão realizados com a Populaçäo LGBT, com roteiro próprio por grupo de população, e discussões registradas em meio eletrónico (áudio) e, posteriomente, transcritas. Cada grupo contará com uma participação média de seis participantes.

\section{Objetivo da Pesquisa:}

Geral:

Analisar o acesso e a qualidade da atençäo integral à saúde da populaçăo de Lésbicas, Gays, Bissexuais, Transexuais e Travestis (LGBT) no Sistema Único de Saúde (SUS).

\section{Especificos:}

(1) Mapear as dimensões do acesso da população lésbicas, gays, bissexuais, travestis e transexuais-LGBT nos serviços de atenção básica, média e alta complexidade, na perspectiva dos usuários, profissionais e gestores.

(2) Identificar e apreender as dimensões da qualidade da atenção integral nos serviços de atenção básica, média e alta complexidade, na perspectiva dos usuários, profissionais e gestores.

(3) Comparar os elementos das dimensöes do acesso e da qualidade identificados com as açöes preconizadas pela Política Nacional de Saúde Integral LGBT.

(4) Identificar as estratégias e as redes para a atençăo à saúde acessadas pela populaçäo LGBT.

Avaliação dos Riscos e Beneficios:

Riscos:

Embora a pesquisadora informe que näo há riscos para os participantes de pesquisa, solicita-se

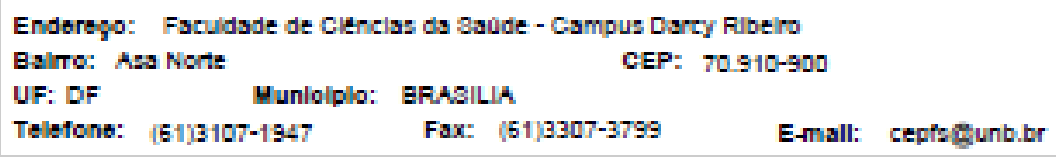




FACULDADE DE CIÊNCIAS DA
SnB
SAUEDE DA UNIVERSIDADE DE Rlotoforma
BRASÍLIA - CEP/FS-UNB

Cartinuagha do Parecte eS2.649

que verifique $o$ item - Pendências - abaixo.

Beneficios:

Serão beneficiados, com este projeto de pesquisa, a populaçăo de lésbicas, gays, bissexuais, transexuais e travestis, os trabalhadores da Estratégia Saúde da Família e os gestores do Sistema Único de Saúde, no âmbito da implantação e institucionalizaçăo da Política Nacional de Saúde Integral de Lésbicas, Gays. Bissexuais, Transexuais e Travestis.

Comentários e Considerações sobre a Pesquisa:

Dados de pesquisa podem identificar elementos relacionados funcionalmente a processos de sofrimento desta populaçäo, decorrentes de discriminaçăo e preconceito, assim como, dados sobre como essas pessoas, cidadăos e cidadäs, promovem e produzem sua saúde e como os serviços de saúde da rede SUS integram este processo.

Considerações sobre os Termos de apresentação obrigatória:

Foram inseridos os seguintes documentos ao processo: (a) carta de encaminhamento da pesquisadora ao CEP-FS/UnB; (b) projeto de pesquisa com planiha de orçamento, sob responsabilidade do Ministério da Saúde, e cronograma; (c) Folha de Rosto, assinada pela Diretora da FS/UnB; (d) Termo de Concordância assinado pela Coordenadora de Atenção Básica de Formosa/GO e Gerente de Regional de Saúde do Norte de Formosa/GO; (e) Termo de Responsabilidade e Compromisso de Pesquisa, assinado pela pesquisadora; (f) TCLE; (g) Termo de Autorização para Utilização de Som de Voz para fins de pesquisa; (h) Lattes da pesquisadora responsável pela pesquisa e equipe.

Recomendaçôes:

Năo se aplica.

Conclusöes ou Pendências e Lista de Inadequações:

(1) Solicita-se à pesquisadora que explicite os procedimentos a serem adotados caso as entrevistas, grupos focais ou questionários eletrônicos provoquem eventuais constrangimentos para os participantes de pesquisa.

Resposta: a pesquisadora esclarece que caso a aplicação do questionário provoque qualquer desconforto ou constrangimento ao participante de pesquisa, este será informado sobre a opção de näo responder à respectiva questäo, ou, ainda, sobre a possibilidade de desistir de participar da pesquisa.

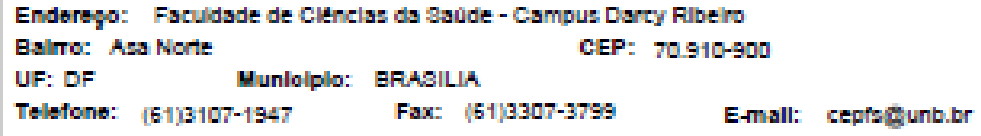




FACULDADE DE CIÊNCIAS DA
SAÚDE DA UNIVERSIDADE DE
BnB

Cartinuaçbe do Parecte es2.643

(2) $O$ cronograma de pesquisa requer atualizaçôes.

Resposta: a pesquisadora provienciou a atualização.

(3) O projeto de pesquisa também foi submetido ao CEP-SESIDF, com os Termos de Concordância das autoridades de saúde do DF?

Resposta: o projeto năo foi submetido ao CEP-SES/DF. No entanto, será submetido à CONEP por se tratar de estudo multicéntrico.

(4) O TCLE deve incluir, além do telefone do CEP-FS/UnB, o e-mail de contato do CEP.

Resposta: as alteraçöes solicitadas foram efetuadas pela pesquisadora.

Situação do Parecer:

Aprovado

Necessita Apreciação da CONEP:

Nằ

Considerações Finais a critério do CEP:

BRASILIA, 19 de Maio de 2014

Assinado por:

Marie Togashi

(Coordenador)

Enderepo: Faculdade de Clenclas da aaude - Campus Darcy Ribeiro

Balro: Asa Norte CEP: $70.910-900$

UF: DF Muniolplo: GRAILIA

Telefone: (61)3107-1947 Fax: (61)3307-3799 E-mall: cepfogerunb.br

Paina 04 de of 


\section{Questionário}

1. Município

2. No segmento LGBT você se considera como: (pode marcar mais de uma questão, se for o caso):
( ) Lésbica
( ) Gay
( ) Bissexual
( ) Transexual
( ) Travesti
( ) Outros:

3. Sua identidade de gênero é (escolha uma das seguintes respostas):
( ) Mulher
( ) Homem
( ) Outros:

4. Qual a sua idade?

5. Considerando a classificação do quesito cor estabelecida pelo Instituto Brasileiro de Geografia e Estatística (IBGE), como você se define?
( ) Branco/a
( ) Preto/a
( ) Pardo/a
( ) Amarelo/a
( ) Indígena
( ) Outros:

6. Em relação a sua vida afetiva, como você se considera?
( ) Casado/a
( ) Em união Estável
( ) Divorciado/a, separado/a
( ) Solteiro/a
( ) Moro junto (não configurando união estável)
( ) Viúvo/a
( ) Outros:

7. Qual a sua orientação sexual?
( ) Lésbica
( ) Gay 

( ) Bissexual
( ) Heterossexual
( ) Outros:

8. Qual é o seu grau de escolaridade?
( ) Ensino fundamental
( ) Ensino médio
( ) Ensino superior
( ) Pós-graduação (especialização)
( ) Pós-graduação (mestrado, doutorado)
( ) Outros:

9. Qual é a sua religião?
( ) Afro-brasileira
( ) Católica
( ) Espírita Kardecista
( ) Protestante
( ) Nenhuma
( ) Outros:

10. Você já foi ou é militante do movimento social?
( ) $\operatorname{Sim}$
( ) Não

11. Em qual faixa salarial você se enquadra?
( ) Até $R \$ 465,00$
( ) $\mathrm{De} R \$ 466,00$ a $\mathrm{R} \$ 930,00$
( ) De $R \$ 931,00$ a $R \$ 1.395,00$
( ) $\mathrm{De} R \$ 1.396,00$ a $\mathrm{R} \$ 1.860,00$
( ) $\mathrm{De} R \$ 1.861,00$ a $\mathrm{R} \$ 2.790,00$
( ) $\mathrm{De} R \$ 2.791,00$ a $6.000,00$
( ) Mais de $\mathrm{R} \$ 6.000,00$

12. Utiliza serviços de saúde suplementar (plano de saúde - privado)?
( ) Sim
( ) Não

13. Considerando que haverá um sorteio aleatório para participação de uma discussão em um grupo focal, você sendo sorteado(a), aceitaria participar dessa discussão a se realizar em um único encontro?
( ) $\operatorname{Sim}$
( ) Não

14. Você tem vínculo com alguma unidade de saúde da família?
( ) $\mathrm{Sim}$
( ) Não

Se sim, qual?

15. Se você aceita participar, como podemos entrar em contato com você? 
E-mail:

Telefone:

Endereço:

Outro meio:

Agradecemos sua participação!!!!

NESP - Núcleo de Estudos em Soúde Pablica SCLN 406 Bloco A 20 andar - Aso Norte - Braslia/DF - CE: 70647-510- Fone: (55++61) 3340-6863

http://www.nespurbbr-nespourbbr 
APÊNDICE- TABELA DE CATEGORIZAÇÃO DOS SUJEITOS

\begin{tabular}{|c|c|c|}
\hline CATEGORIA ANALÍTICA & UNIDADE DE INFERÊNCIA & SUJEITO \\
\hline \multirow{8}{*}{$\begin{array}{l}\text { PERCEPÇÃO CONFUSA } \\
\text { ENTRE UNIVERSALIDADE E } \\
\text { EQUIDADE. }\end{array}$} & $\begin{array}{l}\text { "Acredito que se a gente fizesse algo específico para } \\
\text { eles, estaríamos segregando, fazendo algo especial para } \\
\text { eles. Eu acho que isso seria errado [...] e a necessidade } \\
\text { é a mesma e deve ser atendido na forma que for } \\
\text { preciso". }\end{array}$ & MED1 \\
\hline & $\begin{array}{l}\text { "Eles entram na universalidade, não tem serviços e } \\
\text { ações especificamente dirigidos só para eles ainda" }\end{array}$ & MED3 \\
\hline & $\begin{array}{l}\text { "Não é para ter essa segregação, essa preocupação } \\
\text { específica com eles, na verdade, o que tem que ser } \\
\text { garantido a eles, é o que se garante a coletividade como } \\
\text { um todo". }\end{array}$ & MED3 \\
\hline & $\begin{array}{l}\text { "Um problema a supervalorização desse grupo, } \\
\text { enfraquecer os outros, não é?! Porque tem outros } \\
\text { grupos também: idosos, hipertensos, diabéticos, } \\
\text { crianças, gestantes, portadores de deficiências físicas, } \\
\text { não é?!" }\end{array}$ & MED3 \\
\hline & $\begin{array}{l}\text { "Aqui no consultório, qualquer um tem o acesso, } \\
\text { independente de ser desse grupo ou não. O que tem } \\
\text { prioridade justamente são aqueles já padronizados } \\
\text { oficialmente: idosos, portadores de necessidades } \\
\text { especiais, gestantes e crianças de colo". }\end{array}$ & MED4 \\
\hline & $\begin{array}{l}\text { "Não existe nada especial para eles, exatamente porque } \\
\text { defendemos a ideia que eles devem estar inseridos } \\
\text { dentro da comunidade e sem motivo para que eles } \\
\text { sejam segregados de uma forma ou de outra". }\end{array}$ & MED1 \\
\hline & $\begin{array}{l}\text { "Todos os pacientes são atendidos da mesma forma, } \\
\text { independente de classe, cor, classe econômica ou ser". }\end{array}$ & MED4 \\
\hline & $\begin{array}{l}\text { "A gente não tem nada específico para LGBTT. É } \\
\text { como eu tô te falando, é um acesso universal, } \\
\text { independente de sexo, raça, idade [...] não tem nenhum } \\
\text { programa específico. É igual para todo mundo. A } \\
\text { facilidade ou dificuldade é a mesma". }\end{array}$ & MED5 \\
\hline \multirow{7}{*}{$\begin{array}{l}\text { PATOLOGIZAÇÃO E } \\
\text { ANORMALIDADE }\end{array}$} & $\begin{array}{l}\text { "Acho que eles devem ser inseridos na população } \\
\text { normal para que sejam encarados com naturalidade". }\end{array}$ & MED1 \\
\hline & $\begin{array}{l}\text { "Conversava muito com eles, eles precisam muito de } \\
\text { conversa, conversava: olha cara, aceita, assume, tenha } \\
\text { responsabilidade, até não é porque você é desse jeito ai } \\
\text { que você vai se jogar não, você pode ter um bom } \\
\text { comportamento e ser uma pessoa normal como eu sou, } \\
\text { porra!". }\end{array}$ & MED2 \\
\hline & $\begin{array}{l}\text { "Ele é bem atendido, até porque eu acho, na maneira de } \\
\text { eu ver, eu acho que eles são pessoas especiais, até por } \\
\text { causa do problema do tabu que ainda existe, estão } \\
\text { vencendo uma barreira que já melhorou bastante". }\end{array}$ & MED2 \\
\hline & $\begin{array}{l}{[\ldots] \text { só que eles tem problemas, mas não vamos }} \\
\text { esconder, né? vamos botar pra fora, dizer a verdade, } \\
\text { que eles têm problema, tem! precisa, precisa ter que } \\
\text { ouvir". }\end{array}$ & MED2 \\
\hline & $\begin{array}{l}\text { "Acesso[...] É aquilo que é ofertado para todos, sem } \\
\text { distinção, para o normal e para o gay. }\end{array}$ & MED2 \\
\hline & $\begin{array}{l}\text { "Existe controle da hipertensão, diabetes, tuberculose, } \\
\text { hanseníase, outras patologias, mas LGBT não tem!". }\end{array}$ & MED4 \\
\hline & $\begin{array}{l}\text { "Não existe dificuldade, sempre tem uma maneira que } \\
\text { o paciente seja atendido, se não puder vir, nós vamos a } \\
\text { sua residência [...] Acesso à saúde aqui é boa, você } \\
\text { pode chegar aqui a qualquer hora, sempre tem um }\end{array}$ & MED2 \\
\hline
\end{tabular}




\begin{tabular}{|c|c|c|}
\hline \multirow{8}{*}{$\begin{array}{l}\text { NEGAÇÃO DE BARREIRA AO } \\
\text { ACESSO E IMPUTALIDADE } \\
\text { DA AUSÊNCIA DE PROCURA } \\
\text { DO SERVIÇO AOS PRÓPRIOS } \\
\text { SUJEITOS. }\end{array}$} & $\begin{array}{l}\text { médico pra lhe atender }[. . .] \text { Eu não percebo se há } \\
\text { discriminação entre LGBT e outros pacientes da } \\
\text { população. }\end{array}$ & \\
\hline & $\begin{array}{l}\text { "Hoje em dia, a dificuldade que eles tem é a mesma } \\
\text { dificuldade que qualquer pessoa comum tenha [...]ele é } \\
\text { bem atendido, porque a gente é muito aberto para essas } \\
\text { questões e tudo que está ao nosso alcance, a gente tenta } \\
\text { passar para eles e orientá-los e encaminhá-los. }\end{array}$ & MED6 \\
\hline & $\begin{array}{l}\text { "Porque é uma coisa que já está sendo muito } \\
\text { divulgada, a imprensa divulga muito para não ter } \\
\text { nenhum preconceito. Então eles já assimilaram isso, } \\
\text { eles não têm mais constrangimento, vêm } \\
\text { espontaneamente e assumem tudo. Aqui é porque eu } \\
\text { acho que não tem no bairro [...] Não tenho travestis e } \\
\text { transexuais [...] Lésbica mesmo eu não tenho } \\
\text { nenhuma." }\end{array}$ & MED7 \\
\hline & $\begin{array}{l}\text { "É, eu faço um bom atendimento, faço } \\
\text { esclarecimentos, os cuidados que devem ter, tudo que é } \\
\text { possível dentro da minha função de médica eu faço. } \\
\text { Exames, solicito exames que são necessários, as vezes } \\
\text { eu peço para trazer o parceiro, para vim o casal, para } \\
\text { fazer um melhor esclarecimento. Isso aí eu faço". }\end{array}$ & MED7 \\
\hline & $\begin{array}{l}\text { "Não, não tem impedimento, é por parte deles mesmo, } \\
\text { pessoa não tem, eles se envergonham, ainda é o tabu, } \\
\text { que melhorou bastante, né? melhorou } 60 \% \text {, } \\
\text { antigamente andavam escondido, hoje melhorou muito, } \\
\text { lá no meu interior fico preocupado, já andam tudo solto } \\
\text { já, fazem questão". }\end{array}$ & MED2 \\
\hline & $\begin{array}{l}\text { "Até porque, eles só procuram os médicos como ultimo } \\
\text { recurso na medicina, né? pois já tão com problemas, } \\
\text { antes do problema eles não procuram, pelo menos os } \\
\text { que conheço, todos que me procuraram tão com } \\
\text { problema, isso é pura verdade, não adianta esconder os } \\
\text { fatos". }\end{array}$ & MED2 \\
\hline & $\begin{array}{l}\text { "Eles mesmo, LGBT, não procuram a unidade como } \\
\text { um grupo formado. Se eles não procuram a unidade, se } \\
\text { mobilizam, então nós também não temos a } \\
\text { oportunidade desse relacionamento [...] Mas nós não } \\
\text { temos contato com esse grupo, esse grupo em } \\
\text { momento nenhum nos procurou". }\end{array}$ & MED4 \\
\hline & $\begin{array}{l}\text { "A não ser por um preconceito próprio deles, caso } \\
\text { tenha, mas não pela equipe, pela UBS, de jeito } \\
\text { nenhum! Se tiver, é por eles mesmos, de repente } \\
\text { chegar aqui. Mas pela equipe, pela unidade, não!". }\end{array}$ & MED5 \\
\hline \multirow[t]{4}{*}{$\begin{array}{l}\text { BAIXA DEMANDA DO GRUPO } \\
\text { LGBT OU INVISIBILIDADE DA } \\
\text { CONDIÇÃO }\end{array}$} & $\begin{array}{l}\text { "Nunca atendi nenhum desses pacientes, mas quando } \\
\text { vem, acredito que sejam bem atendidos } \\
\text { independentemente de sexo [...] Nós não temos esse } \\
\text { tipo de paciente aqui, eu nunca atendi, nunca se dirigiu } \\
\text { pra cá pra nós". }\end{array}$ & MED2 \\
\hline & $\begin{array}{l}\text { "Existe ainda um complexo, né? por alguns, outros } \\
\text { não, né? fazem questão de ser [...] uns fazem questão } \\
\text { de aparecer e outros não, fazem questão de se } \\
\text { esconder". }\end{array}$ & MED2 \\
\hline & $\begin{array}{l}\text { "Como a comunidade é reduzida, pelo menos aquelas } \\
\text { que sejam sabidas, que sejam bem expostos, que tenha } \\
\text { algum grau de revelação, a demanda é pequena, é } \\
\text { curta". }\end{array}$ & MED3 \\
\hline & $\begin{array}{l}\text { "Na verdade, quando o paciente procura a nossa equipe } \\
\text { [...], a gente não procura identificar sua opção sexual } \\
\text { [...] na nossa equipe não existe dificuldade, até porque }\end{array}$ & MED4 \\
\hline
\end{tabular}




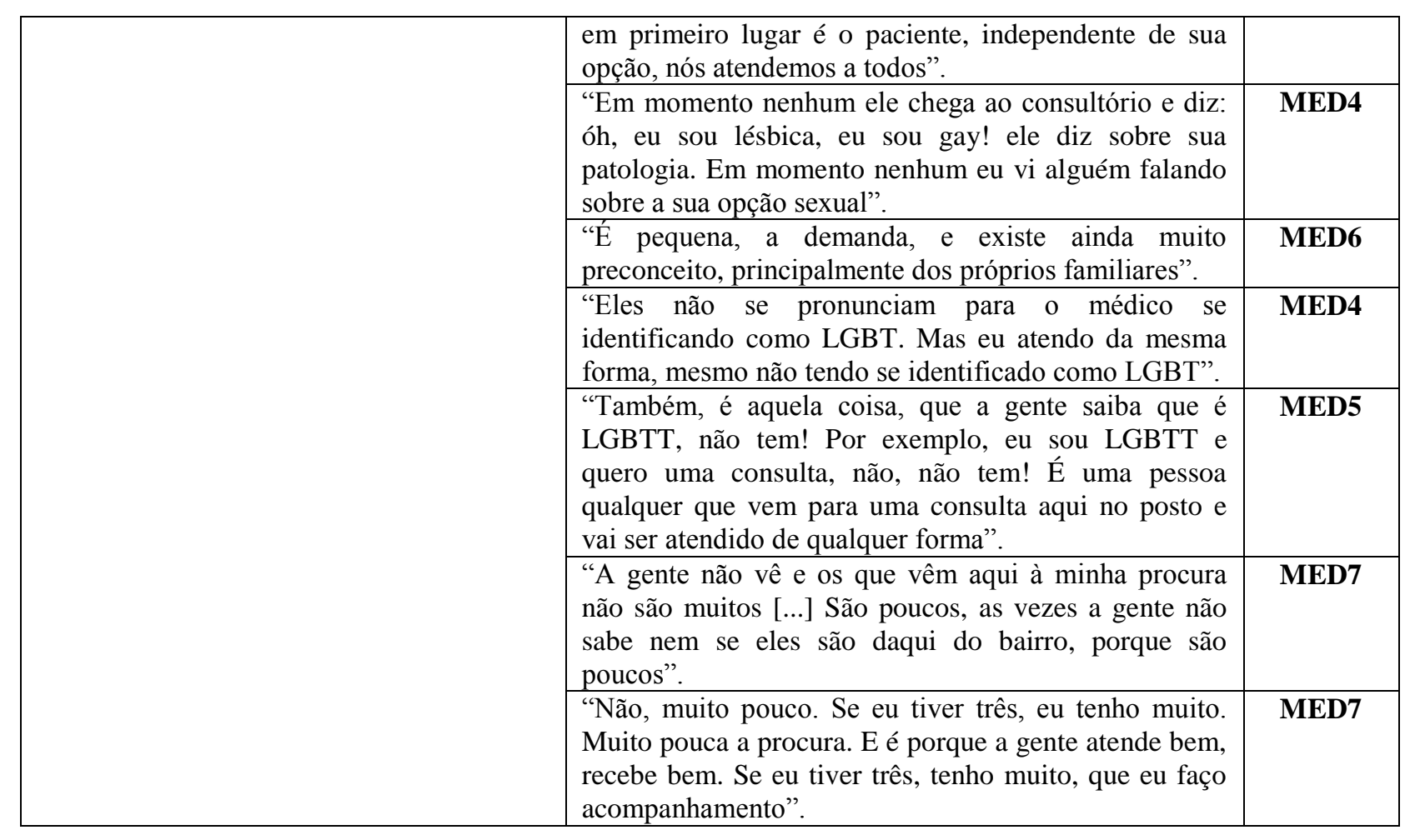

